\title{
Invited review: Effectiveness of precalving treatment on postcalving udder health in nulliparous dairy heifers: A systematic review and meta-analysis
}

\author{
S. Ali Naqvi, ${ }^{*} \dagger$ Diego B. Nobrega, ${ }^{*}$ Paul E. Ronksley, $†$ and Herman W. Barkema* ${ }^{* 1}$ \\ *Department of Production Animal Health, Faculty of Veterinary Medicine, and \\ †Department Community Health Sciences, Cumming School of Medicine, University of Calgary, Calgary, AB, T2N 4N1, Canada
}

\begin{abstract}
Clinical mastitis affects $3 \%$ of primiparous dairy cattle (heifers) in the first month after calving. Additionally, the prevalence of intramammary infection (IMI) in the months before first calving is high, resulting in a high prevalence of heifers calving with IMI. Precalving therapy is an accepted recommendation for reducing mastitis in multiparous cows, but prophylactic treatment for heifers is uncommon in North America. Objectives of this study were to (1) quantify changes in postcalving udder health in heifers following application of a precalving treatment; (2) compare effectiveness among various types of treatments; and (3) compare effectiveness of various types of treatments against specific pathogens. A systematic review was conducted comparing interventions aimed at improving udder health in heifers. Of 62 included studies, 48 clinical trials were used in a meta-analysis. Data were synthesized using a random effects model for meta-analysis, followed by sub-group analyses comparing treatment types, and specific pathogens with statistical testing using meta-regression. Occurrence of mastitis (defined as elevated somatic cell count, clinical mastitis, and IMI) was reduced in treated heifers compared with untreated controls with a pooled risk ratio of treated to untreated heifers of 0.56 (95\% confidence interval: 0.47 to 0.67 ). Upon stratification by treatment types, teat sealants and combination therapies (vaccines and antimicrobials; antimicrobials and teat sealants; and all 3) were most effective at improving udder health with pooled risk ratios of 0.40 (95\% confidence interval: 0.30 to 0.52 ) and 0.34 (95\% confidence interval: 0.25 to 0.45$)$, respectively. Antimicrobials and vaccines also reduced occurrence of IMI and subclinical and clinical mastitis when compared with untreated heifers. Al-
\end{abstract}

Received December 15, 2017.

Accepted January 19, 2018.

${ }^{1}$ Corresponding author: barkema@ucalgary.ca though variation was observed in the pathogen-specific effectiveness of treatments at reducing rates of disease, antimicrobials, teat sealants, and combinations of vaccines or teat sealants with antimicrobials were consistently effective, whereas vaccines were only effective for contagious pathogens. Recommendations for use of antibiotics should consider their relative benefit while also considering potential for increasing antimicrobial resistance.

Key words: heifer, mastitis, prepartum, treatment, meta-analysis

\section{INTRODUCTION}

Mastitis is one of the most economically important diseases in the dairy industry (Seegers et al., 2003) as it has implications not only for animal health and welfare, but also for milk quality and production. The occurrence of mastitis is not only high in lactating cows, but also in heifers in the first weeks after calving (De Vliegher et al., 2012; Naqvi et al., 2018). Heifers with (sub)clinical mastitis, IMI, or both are often not identified because they are not milked, and therefore their teats and milk typically are not examined (De Vliegher et al., 2012). However, the prevalence of IMI in the months before the first calving is high, resulting in a high prevalence of heifers calving with IMI (De Vliegher et al., 2012).

Although nonlactating heifers are not included in standard mastitis prevention plans like the 5-point schedule (Neave et al., 1969) or the relatively recent NMC 10-point plan (NMC, 2004), a variety of treatments to prevent or cure IMI in these heifers has been studied. Following a review on heifer mastitis (De Vliegher et al., 2012), the NMC published a 10-point plan specifically for controlling heifer mastitis. In this new set of recommendations, only 2 were specific to heifers, whereas the others were similar to recommendations in the first 10-point plan. Some commonly used precalving treatments are vaccines, non-antimicrobial teat sealants, short- and long-term antimicrobials, and combinations of these treatments. Many studies have 
been conducted on effects of a single type of treatment in heifers (Edinger et al., 2000; Santos et al., 2004; Roy et al., 2007; Pellegrino et al., 2008). However, very few studies have compared types of therapies, and their results have been inconsistent (McDougall et al., 2009).

Previous studies have demonstrated and quantified a net positive benefit of various precalving treatments (Ataee et al., 2009; Duplessis et al., 2014; Passchyn et al., 2014), as well as characterizing pathogens causing ensuing infections. Systematic reviews have been conducted on the effectiveness of antimicrobial treatments in heifers (Nickerson, 2009), non-antibiotic strategies for prevention and control of mastitis in heifers (McDougall et al., 2009), and vaccines for lactating cows (Middleton et al., 2009), whereas reviews of postpartum mastitis and mastitis control have also described preventive treatments in heifers and lactating cows (Pyörälä, 2008; De Vliegher et al., 2012). However, no review has focused on quantifying treatment effectiveness in heifers, or compared efficacy of precalving treatment types using a meta-analysis to estimate overall effect size. Objectives of this study were therefore to (1) synthesize results from previous studies to determine and compare effectiveness of various types of precalving therapies aimed at improving udder health; and (2) determine and compare effectiveness of various types of precalving therapies against types of pathogens, grouped by etiology.

\section{MATERIALS AND METHODS}

This systematic review and meta-analysis was conducted following a pre-specified protocol created using the Preferred Reporting Items for Systematic Review and Meta-Analysis Protocols guidelines (Shamseer et al., 2015).

\section{Data Sources and Literature Search}

Online databases searched were CAB Abstracts, Web of Science (complete collection), AGRICOLA, MedLine, and SCOPUS, from inception to September 2017. In addition, 2 individuals (SAN and DBN) hand-searched references of existing reviews on the subject. Gray literature consisted of a search through all available conference proceedings in relevant conferences, as well as websites of pharmaceutical companies and the Proceedings of the World Buiatrics Congress (2000-2014) on The International Veterinary Information Service website. In addition, proceedings of the American Dairy Science Association (1957-2017) and National Mastitis Council (NMC; 1989-2017) annual meetings were searched. Experts in the field were also contacted for information about potential ongoing or unpublished studies, and were identified through the review process or through direct communications at conferences (Mastitis Research Worker's meeting in November 2016, and NMC annual meeting in January 2017). No publication date or language filter was applied to the search, and the search was conducted as recommended (Egger et al., 2008).

The search strategy was split into 3 main components corresponding to the population of interest, intervention type, and study outcome. The population of interest included primigravid to primiparous dairy cattle, with the intervention having to be applied during pregnancy and udder health measured after calving. The interventions of interest were any kind of treatment applied precalving aimed specifically at improving udder health. This was intended to exclude interventions such as feed additives intended to improve overall health and growth, as it did not address the primary question of targeted and individual treatment of heifers. Full details of the search terms used are provided (Appendix).

\section{Study Eligibility and Selection}

An initial screen of all titles was performed by 2 individuals (SAN and DBN) to determine if manuscripts were eligible for full text review for inclusion in the systematic review. If the title was not detailed enough to decide about moving forward with full-text screening, the abstract was scrutinized by one of the reviewers (SAN) to determine whether it was eligible. A manuscript needed to meet 2 conditions to be considered for a full text review: (1) The manuscript had to report on primary data; and (2) the manuscript had to report on an intervention aimed at improving udder health (no vaccines for other conditions such as leucosis, or treatment with anthelminthic products), although it may not necessarily be the primary aim of the study (comparing mastitis in 2 regions where a particular product may not be allowed).

This initial screen was designed to be fairly broad to encompass as many potentially relevant manuscripts for full text review. A full text review was then conducted on all of these screened manuscripts to ensure that some aspect of intervention was addressed in the manuscript. The reason for this full text screening step in the systematic review was that the second condition described above could have resulted in manuscripts whose primary goal was not assessing intervention effectiveness, but was included as a covariate in their analysis. As it was not the primary goal of the study, it may not have been reported in the abstract and a full text screening would capture these manuscripts. 


\section{Identification of Manuscripts for Eligibility in the Systematic Review and Meta-Analysis}

The same 2 individuals (SAN and DBN) reviewed full text manuscripts identified after the 2 screening stages described in the previous section using the following criteria to select manuscripts eligible for inclusion in the systematic review and meta-analysis.

- Population $=$ primigravid/primiparous dairy cattle (if the primary study population was not primiparous dairy cattle, the manuscript must stratify and report on them separately from older animals).

- Intervention $=$ any sort of treatment given after confirmed pregnancy, before calving or on the day of calving that was aimed specifically at improving udder health. Studies that did not assess treatment effectiveness as a primary goal (described in the previous section) were excluded from the systematic review and meta-analysis because they would not be designed around that variable and pooling would not be appropriate.

- Comparison $=$ a treatment must be compared with either another treatment, or no treatment at all.

- Outcome $=$ postcalving prevalence or incidence of (1) clinical mastitis (CM); (2) subclinical mastitis (SCM; elevated SCC); or (3) IMI (presence of bacteria in the milk) reported within 2 mo after first calving.

- Study design = randomized controlled trials or observational cohort studies.

The screening of manuscripts was designed to capture studies comparing precalving treatments in heifers to each other or to untreated heifers in their association with incidence of udder disease postcalving. Only randomized controlled trials were meta-analyzed, whereas results from observational cohort studies were included descriptively in the discussion. Agreement between reviewers (SAN and DBN) regarding study inclusion was quantified using a kappa score and percent agreement, and any disagreements were resolved by the last author (HWB).

\section{Study Quality Assessment and Data Extraction}

Study quality and risk of bias was assessed using the Systematic Review Centre for Laboratory Animal Experimentation (SYRCLE) tool (Hooijmans et al., 2014). The SYRCLE tool is based on the Cochrane Risk of Bias tool (Higgins et al., 2011), with some items modified or added to fit better with risk of bias in experimental trials in animals. Briefly, the SYRCLE tool consists of 10 items, corresponding to 5 types of bias: selection, performance, detection, attrition, and reporting bias. Risk of selection bias is evaluated through considering allocation sequence generation, subject baseline characteristics, and allocation concealments. Performance bias is evaluated by considering random housing of heifers and blinding when assigning treatments. Detection bias is assessed by evaluating randomization of subjects during outcome assessment and blinding of outcome assessors. Attrition bias is assessed by evaluating the study's reporting on incomplete outcome data. Lastly, reporting bias is assessed by evaluating outcomes on which studies reported, as well as outcomes that were excluded. A study was considered to be at high risk of a given type of bias if it had failed to address over half of the sources of error contributing to that given type; moderate risk of bias if they failed to address at least 1, but not more than half; and low or no risk of bias if they did not have any sources of error from a given type of bias.

Data were extracted using a single electronic form using Microsoft Excel (Microsoft Corp., Redmond, WA). Study characteristics extracted were (1) country of study, (2) year of publication, (3) breed, (4) intervention type(s), and (5) time of intervention application. As management decisions are based on anticipated calving dates, the intended or median of intended application times was recorded in the extraction form (e.g., for 2 to 3 wk precalving, the number taken was $17.5 \mathrm{~d}$ ). Outcome characteristics recorded, often multiple for a study, were (1) type of outcome defined as cure rate of existing IMI, SCM, IMI (and its definition), and CM; (2) time of outcome measurement or follow-up in the case of CM; and (3) numbers of individuals (animals or quarters depending on the study) and cases per treatment arm of the study. For studies where postcalving samples were collected on multiple days, the earliest sample that was not the day of calving was used for outcome extraction. Numbers in treatment arms were pooled by intervention or control and type of intervention depending on possible stratification in metaanalyses.

\section{Statistical Analyses}

All statistical analyses were performed using the "metafor" package (Viechtbauer, 2010) in R version 3.4.2 (R Core Team 2017, R Foundation for Statistical Computing, Vienna, Austria). For all analyses, a $P$ value $<0.05$ was considered significant, and a $0.05<P$ value $<0.10$ was considered a tendency for significance. 
Results from randomized clinical trials were pooled using a random-effects meta-analysis, as no observational studies were included in the systematic review. Randomized clinical trials that did not report numbers of individuals and only ratios were not included in the meta-analysis but were included only descriptively. A mixed effects model was selected given the underlying heterogeneity in intervention and population characteristics, and the fact that studies often had multiple treatment types and outcomes. Effect sizes were pooled as risk ratios ( $\mathbf{R R}$ ) because it is most intuitively interpretable in terms of detecting a benefit/harm. All pooled estimates and stratified meta-analyses were visualized using forest plots, and homogeneity was assessed using the Cochrane Q statistic for significance and $I^{2}$ statistic to quantify the amount of variation due to study heterogeneity. The primary question concerning therapy type was statistically tested using meta-regression, and heterogeneity was then explored by stratifying on relevant variables of practical interest: type of outcome and bacterial species of infection. Variation in effectiveness by pathogen type was addressed through a combination of meta-regression and subgroup analyses. Sensitivity and specificity to detect IMI varies considerably among IMI definitions (Andersen et al., 2010; Dohoo et al., 2011a,b), so a meta-regression was conducted to determine whether effect size estimates with rates of IMI differed between studies that described their IMI definition and those that only provided details for culturing. Questions related to effects of study quality or design (abstract versus full text, disease definitions) were also addressed using meta-regression. Publication bias for the primary outcome of interest (mastitis of any form) was assessed using a funnel plot of the RR with the standard error of the RR. Asymmetry was tested using Egger's regression test for small study effects, and visualized with a graph of study variance against the natural $\log$ of the RR.

\section{RESULTS}

\section{Description of Studies}

Search Results. Numbers of studies included at various stages of the review process are shown (Figure 1). Briefly, a total of 974 unique records were identified, with most coming from the database search $(\mathrm{n}=1,245$ before duplicate removal) and a small number being identified through the described gray literature review ( $\mathrm{n}=44$ before duplicate removal). After screening abstracts, 82 peer-reviewed manuscripts were identified for a more thorough full-text review, along with 31 records from conference proceedings. A small number of
non-English manuscripts were identified: Portuguese (n $=1)$, German $(\mathrm{n}=3)$, Dutch $(\mathrm{n}=1)$, Czech $(\mathrm{n}=1)$, and Italian $(\mathrm{n}=1)$. These manuscripts were reviewed using the pre-specified criteria by colleagues with fluency in the respective languages.

Studies Eligible for Inclusion in the Systematic Review. Forty studies from published manuscripts were included in the systematic review, of which 38 were eligible for inclusion in the meta-analysis. All included peer-reviewed manuscripts reported results from clinical trials; 2 could not be included in the meta-analysis because they did not report numbers of outcomes, rather relative measures such as $\mathrm{RR}$ and odds ratios. In addition, 22 studies from conference proceedings or abstracts were included in the systematic review. Ten conference proceedings provided enough detail in their results to be eligible for meta-analysis, whereas others were discussed only descriptively. Records from 48 studies were included in the meta-analysis, although multiple records were included for many studies because they compared multiple treatment types (Table 1). A detailed description of the specific products used in each study is provided (Appendix Table A1).

Risk of Bias in Studies Included. Design characteristics of all full-text manuscripts that are important for risk of bias are described (Table 2). Based on the SYRCLE guidelines, all studies were at high risk for at least one type of bias. The majority of studies were at moderate risk of selection bias $(\mathrm{n}=27)$, with 2 being at low/no risk of selection bias. Allocation sequence generation was often systematic rather than completely random, and baseline animal characteristics were described in most studies $(\mathrm{n}=30)$. The largest type of bias that this pool of studies was at risk for was detection/performance bias, as most did not describe blinding or randomized animal housing. Most ( $\mathrm{n}=$ 31) studies adequately addressed incomplete data by providing numbers of heifers at each stage of the study, with reasons provided for their removal or exclusion from the trial minimizing risk of attrition bias. No studies were at risk of reporting bias, as they all either provided justification for outcomes measured or they were selected in part based on their reporting of outcomes.

Another aspect of variability among studies and a possible source of bias was how they defined outcomes (Table 3), IMI in particular. Many studies $(\mathrm{n}=16)$ only described culturing details for their milk samples, without a strict definition of what was considered an IMI. Risk ratio for IMI did not differ between treated and untreated heifers when comparing the 2 groups of studies $(P=0.93)$. Definition of IMI was not used in any subsequent analyses, or considered for stratification. 


\section{Effectiveness of Treatment}

Overall Effect Size. The overall RR of udder disease of any sort in treated compared with untreated heifers was 0.60 (95\% CI: 0.47 to 0.67 ), demonstrating a reduction in udder diseases after calving in treated compared with untreated heifers $(P<0.0001)$. Effect size estimates from abstracts/proceedings tended to be slightly lower and had more variance than estimates from full-text manuscripts $(P=0.08$; Figure 2$)$, but their inclusion did not have an effect on overall effect size $(\mathrm{RR}=0.60$ for full-text manuscripts alone; $\mathrm{RR}=$ 0.57 for a combined meta-analysis). All further analyses were conducted on results from both full-text manuscripts and abstracts/conference proceedings without stratification.

Effect Size by Outcome Type. The majority of records $(\mathrm{n}=34)$ used IMI as the outcome, whereas 15 records assessed CM and 2 assessed SCM. Effect size estimates for CM tended to be lower than those for IMI

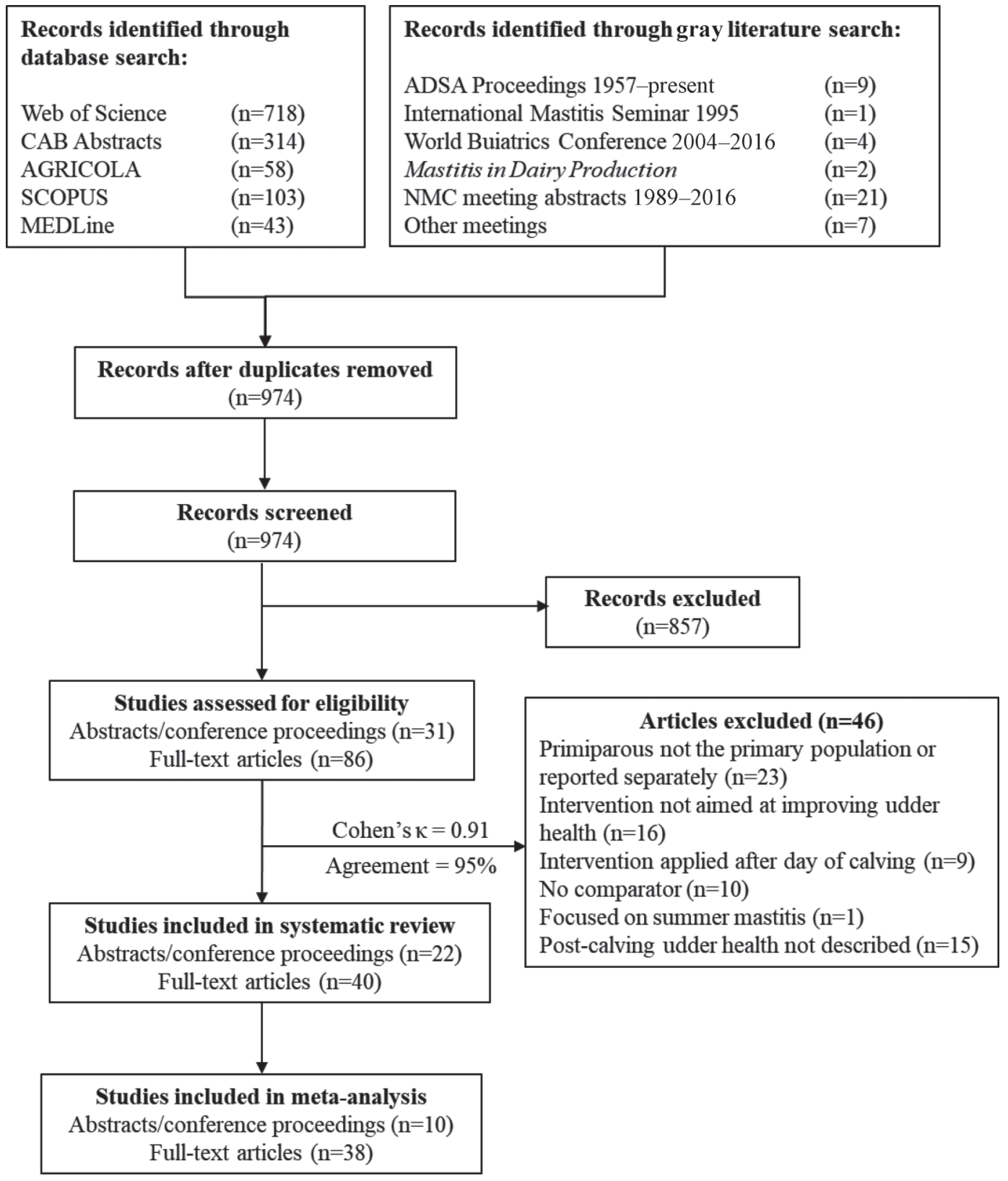

Figure 1. Flow diagram of the manuscript selection process. ADSA = American Dairy Science Association; NMC $=$ National Mastitis Council. 


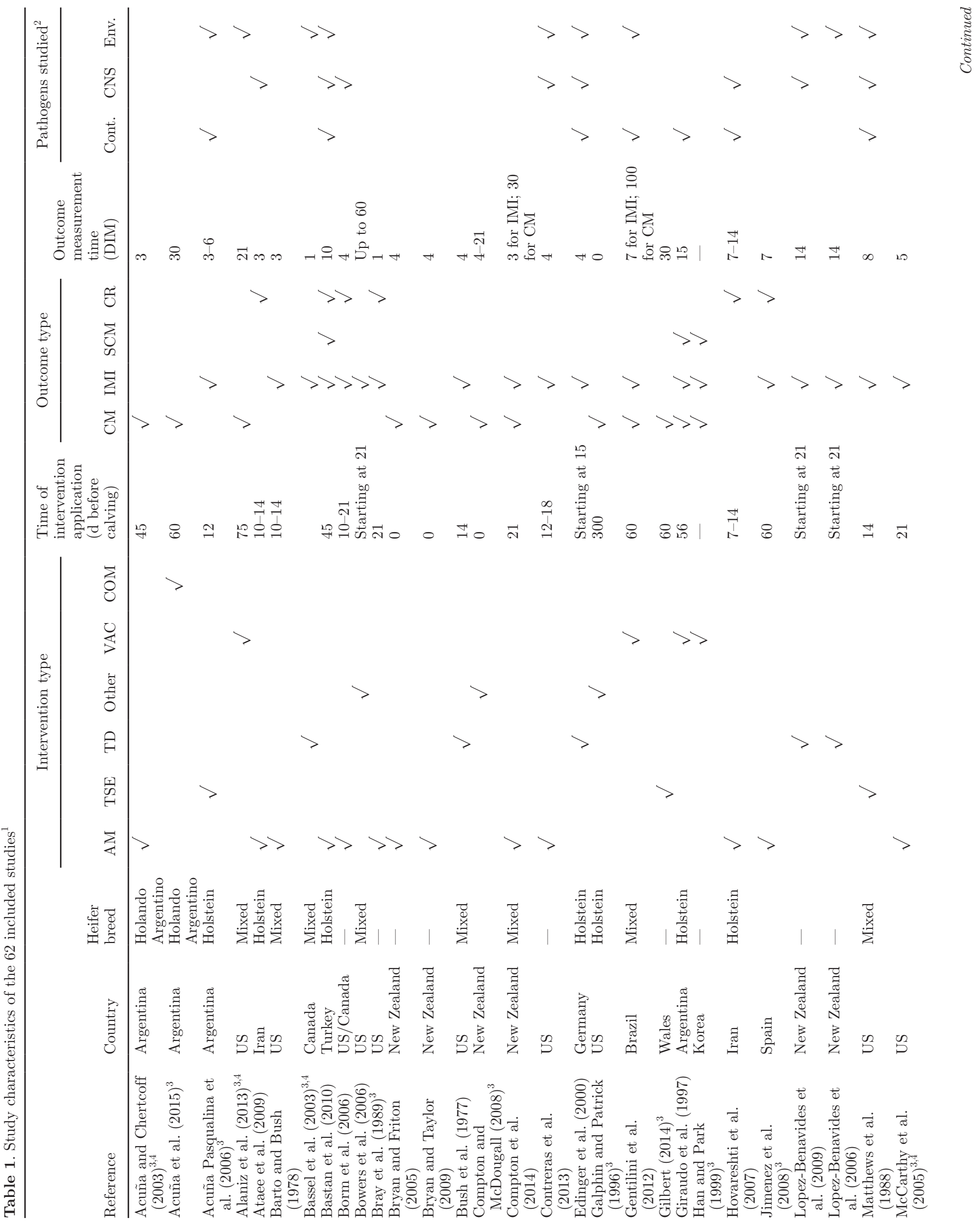


INVITED REVIEW: PREVENTIVE TREATMENT OF HEIFER MASTITIS

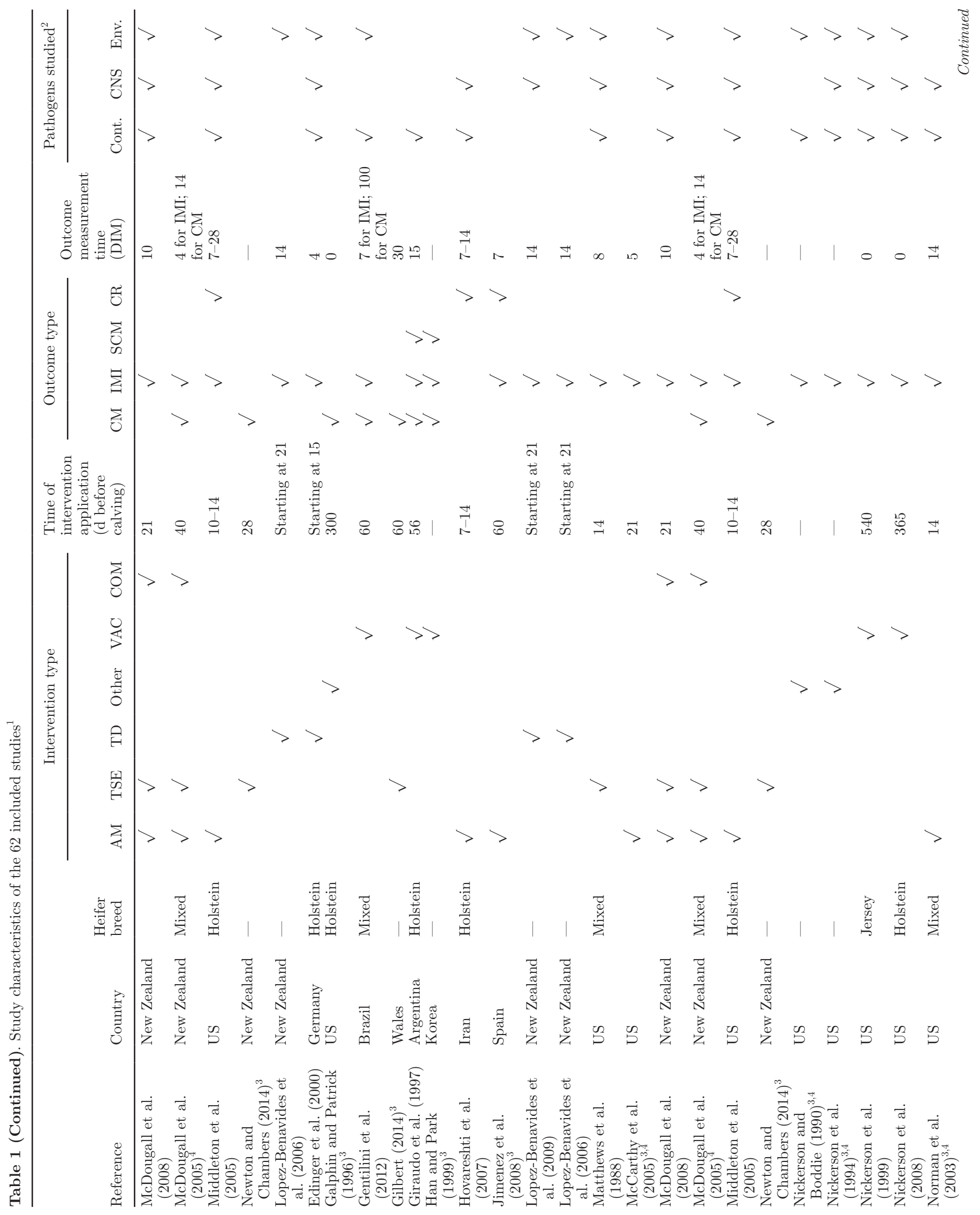


NAQVI ET AL.

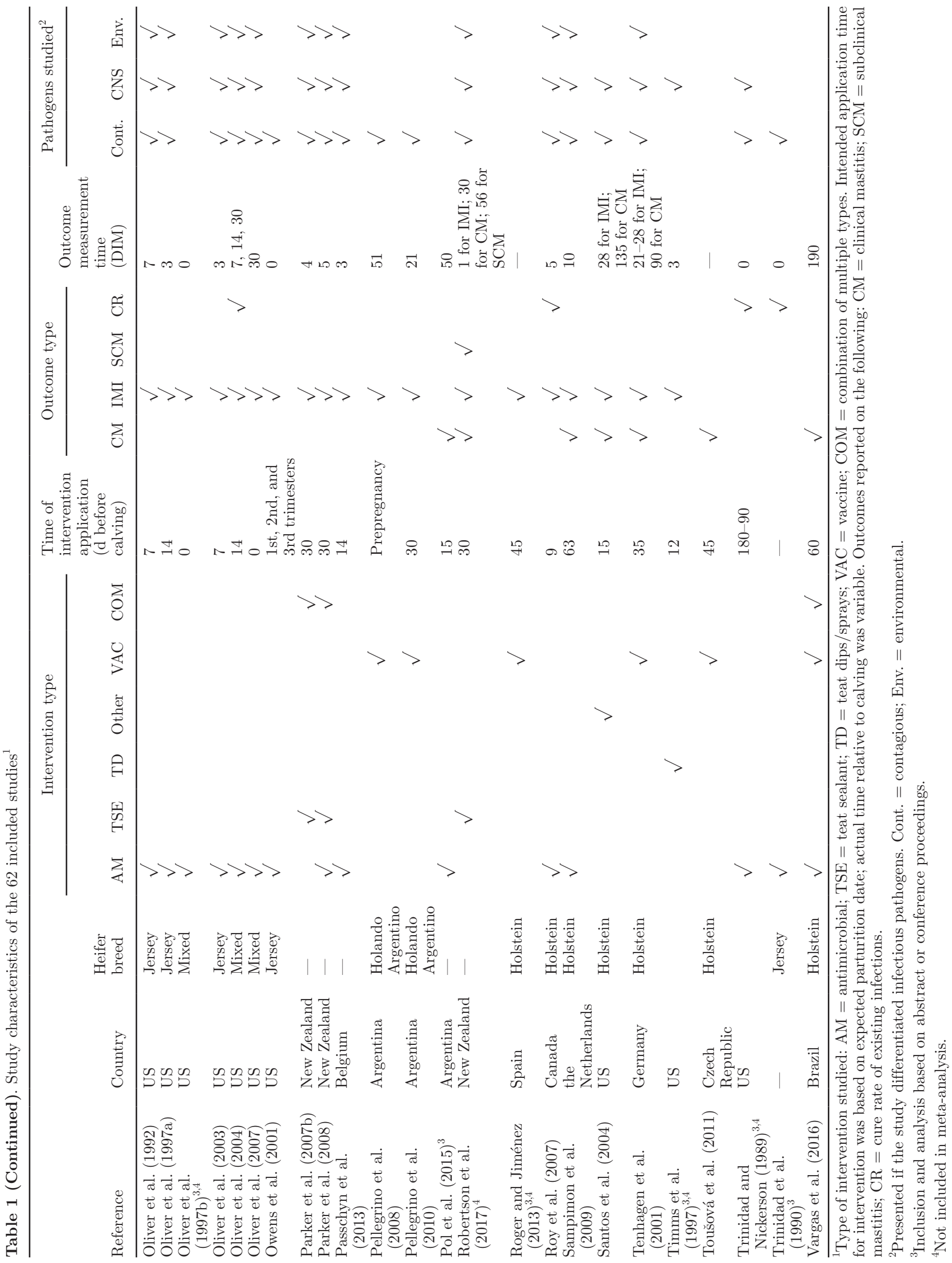


INVITED REVIEW: PREVENTIVE TREATMENT OF HEIFER MASTITIS

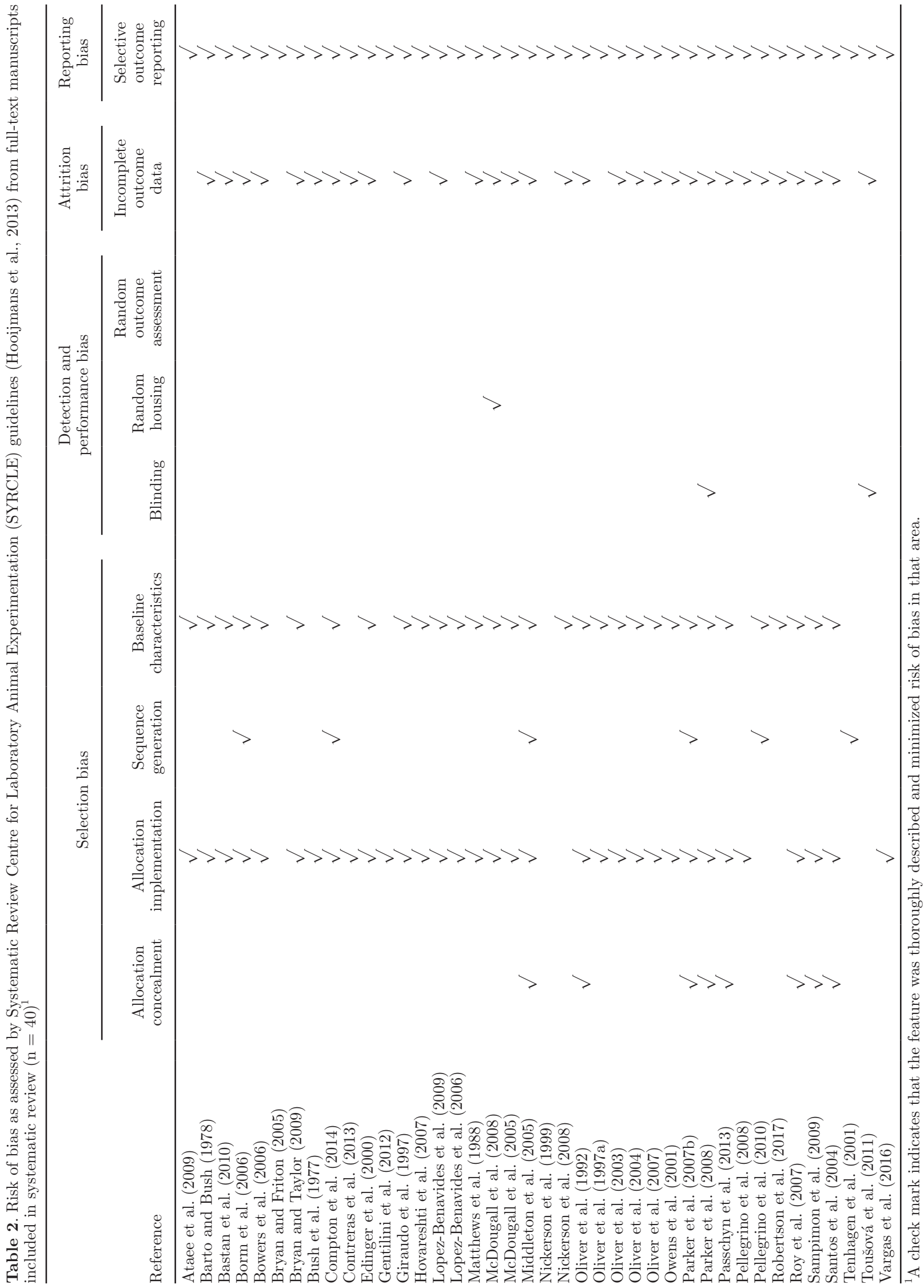


$(P=0.07)$, but tended to be higher than those for SCM $(P=0.06$; Table 4$)$. For subsequent meta-analyses and regressions, all outcomes other than cure rate were combined through a random-effects term included for outcome type within studies to account for any withinstudy correlation. Risk of cure of existing IMI following precalving treatment with antimicrobials was higher than spontaneous cure with no treatment $[\mathrm{RR}=1.63$ (95\% CI: 1.19 to 2.25 ); $P=0.003$ ].

Effect Size by Therapy Type and Pathogen Type. A meta-regression on treatment type using CM, SCM, and IMI as outcomes resulted in a difference in effectiveness among treatment types (Table 5). Teat sealants and combination therapies were the most effective treatments $(P<0.0001)$, although antimicrobials, vaccines, and other treatments still reduced risk of CM, SCM, or IMI compared with untreated controls $(P<0.0001)$. Teat disinfection before calving did not reduce udder disease compared with untreated controls. Records not included in the meta-analysis also reported similar patterns - antimicrobials were effective at preventing CM and IMI, as well as curing existing IMI. Farms observed longitudinally had decreasing prevalence of IMI and incidence of CM around calving after incorporating precalving antimicrobial treatment into heifer management (Acuña and Chertcoff, 2003).

Table 3. Outcome definitions in full-text manuscripts included in the systematic review $(\mathrm{n}=40)$

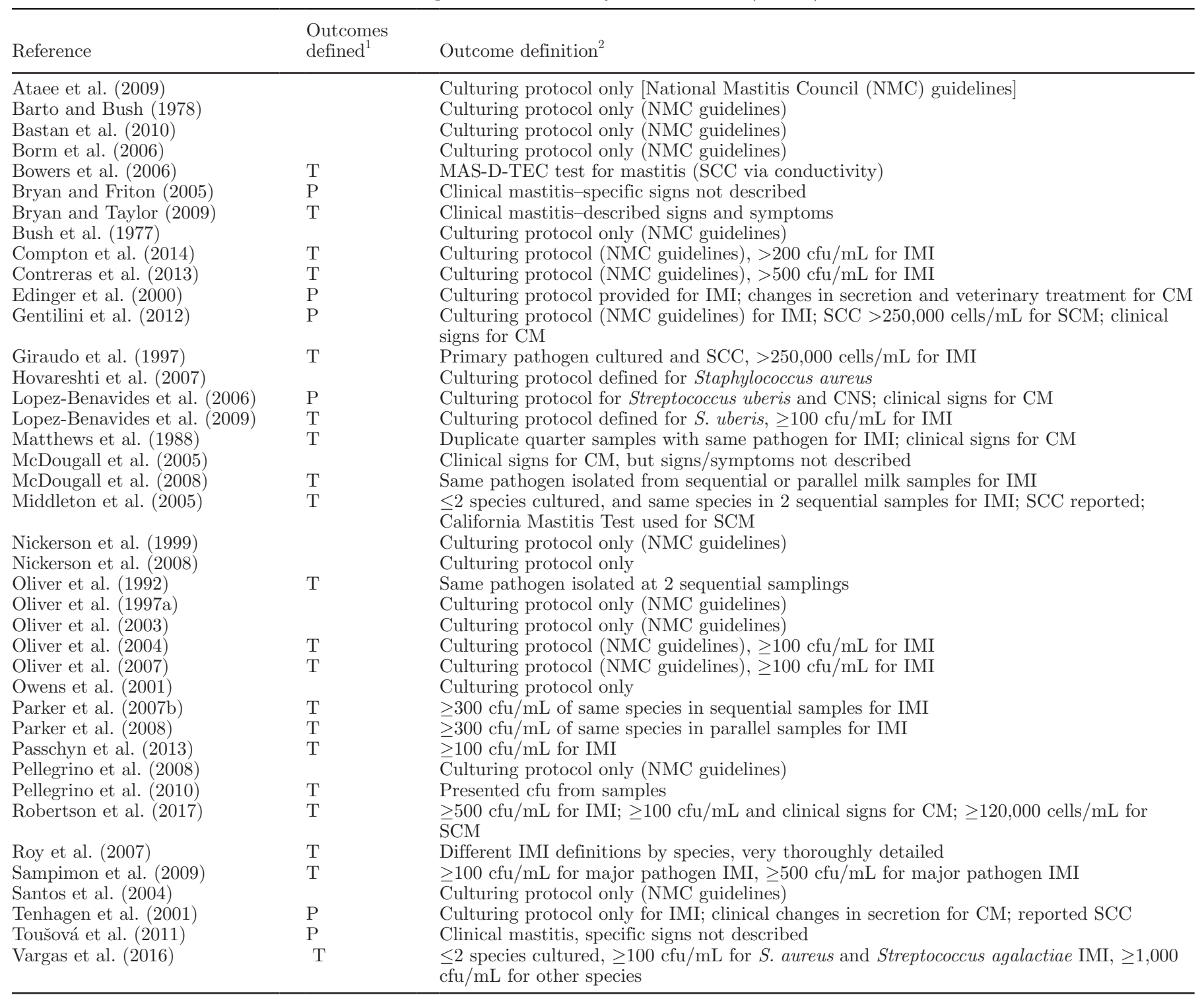

${ }^{1} \mathrm{~T}=$ definitions were thoroughly described; $\mathrm{P}=$ definitions were partially described.

${ }^{2} \mathrm{SCM}=$ subclinical mastitis; $\mathrm{CM}=$ clinical mastitis. 
Other effective management strategies were the use of physical intramammary devices (Nickerson and Boddie, 1990), implementing fly control for heifers on pasture (Nickerson et al., 1994), and earlier removal of calves after calving to prevent suckling (Compton and McDougall, 2008).

Although studies differentiated culture results to varying levels of detail, pathogens were grouped into 3 categories: contagious (Staphylococcus aureus, Streptococcus agalactiae), environmental (Escherichia coli, non-agalactiae streptococci), and CNS. Subgroup analyses including meta-regression on treatment type were conducted using the 3 categories as outcomes (Table 6). Antimicrobials, teat sealants, and vaccines all presented similar reductions $(\mathrm{RR}=0.51,0.40$, and 0.56 , respectively) in contagious pathogen CM and IMI compared with untreated controls. Only 1 study reported on teat dips/sprays (Edinger et al., 2000) and 1 on combination therapies (McDougall et al., 2008); in both studies, the 2 therapies did not change occurrence of CM or IMI compared with controls. Manuscripts not included in the pooled estimate also reported a reduced incidence of CM and IMI by contagious pathogens when heifers received precalving treatment with antimicrobials, and

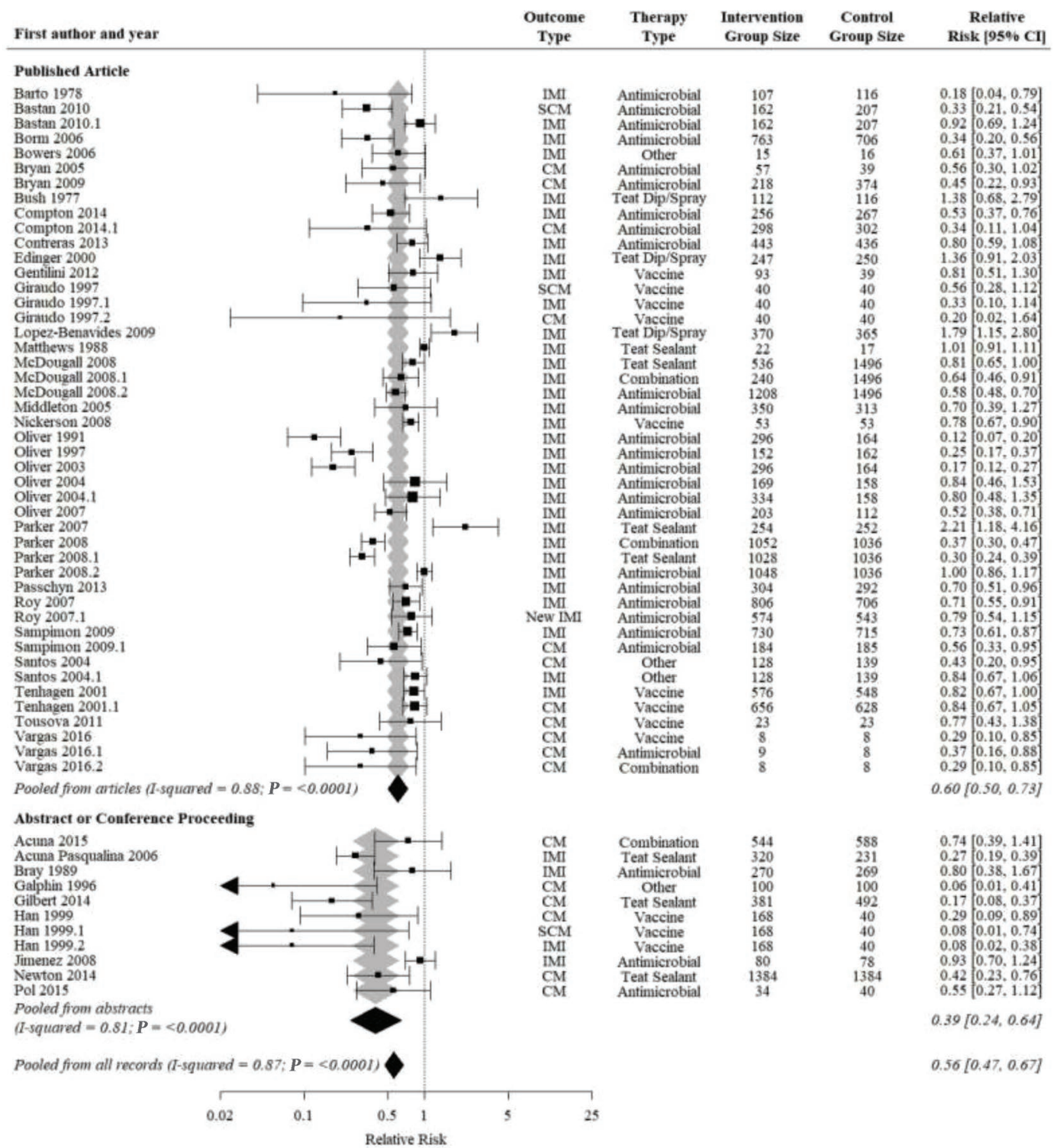

Figure 2. Forest plot of effect size estimates from all $(n=48)$ studies included in the meta-analysis assessing effectiveness of precalving therapy at improving postcalving udder health in dairy heifers. Size of boxes reflects relative size of effect estimate; diamonds represent pooled estimates within strata. $\mathrm{CM}=$ clinical mastitis; new IMI = IMI that was not present precalving; $\mathrm{SCM}=$ subclinical mastitis $($ defined as elevated $\mathrm{SCC}$. 
Table 4. Meta-regression of records included in a systematic review precalving therapies for improving udder health in primiparous dairy heifers on the outcome used to assess udder health

\begin{tabular}{lccl}
\hline Outcome type & Risk ratio $^{1}(95 \% \mathrm{CI})$ & No. of records & Heterogeneity $^{2}$ \\
\hline Clinical mastitis & $0.50(0.39-0.64)$ & 15 & $I^{2}=0.85$ \\
IMI & $0.61(0.51-0.74)$ & 34 & $\mathrm{Q}=343.5$ \\
Subclinical mastitis $^{3}$ & $0.30(0.18-0.50)$ & 2 & $P<0.0001$ \\
\hline
\end{tabular}

${ }^{1}$ Ratio of risk of infection in treated heifers to risk of infection in untreated controls.

${ }^{2}$ Heterogeneity refers to residual heterogeneity from meta-regression model attributed to differences among studies. $I^{2}=$ statistic to quantify the amount of variation due to study heterogeneity; Q $=$ Cochrane Q statistic for significance.

${ }^{3}$ Subclinical mastitis defined as a heifer having an elevated SCC (measured by electrical conductivity of milk, the California mastitis test or a quantified SCC $>120,000$ or 250,000 cells $/ \mathrm{mL}$ ).

also when fly control was implemented for precalving heifers on pasture.

Teat sealants and combination therapies reduced occurrence of CM and IMI with environment pathogens over untreated controls $(\mathrm{RR}=0.27$ and 0.25 , respectively; Table 6). Antimicrobials, teat disinfection, and vaccines did not have any benefit compared with untreated controls, but 2 studies not included in the meta-analysis (Nickerson et al., 1994; Tenhagen et al., 2001 ) reported a reduction of clinical signs during $E$. coli IMI following precalving vaccination. Fly control for heifers on pasture reduced Streptococcus spp. IMI. Studies reporting on CM and IMI where CNS were isolated reported a reduction compared with controls in heifers treated with antimicrobials, teat-sealants, and combination therapies, with combination therapies having the greatest reduction $(\mathrm{RR}=0.34)$, and similar conclusions were drawn from studies not included in the meta-analysis. Vaccines did not reduce CM and IMI with CNS occurrence compared with untreated controls. Due to only single studies assessing other therapies and teat dips/sprays, pooling was not possible, but neither demonstrated a reduction in occurrence of CM and IMI with CNS compared with untreated controls.

\section{Meta-Analysis Statistics}

Heterogeneity. Significant heterogeneity was present in all analyses. Mixed effects meta-analysis using all records with random effects for outcome type and intervention type had an overall $I^{2}=0.87(\mathrm{Q}=439.28$, $P<0.0001$ ). Introducing outcome type as a moderator did not reduce heterogeneity noticeably; $I^{2}=0.85(\mathrm{Q}$ $=343.54, P<0.0001$ ), nor did conducting a metaregression using outcome type affect heterogeneity; $I^{2}=$ $0.85(\mathrm{Q}=369.78, P<0.0001)$. Sub-group analyses by pathogen type led to reductions in residual heterogeneity, except for the CNS analysis: contagious pathogen analysis $I^{2}=0.29(\mathrm{Q}=39.36, P=0.03)$; environmental pathogen analysis $I^{2}=0.57(\mathrm{Q}=71.77, P<0.0001)$; CNS analysis $I^{2}=0.88(\mathrm{Q}=212.71, P<0.0001)$.

Publication Bias. Based on visual assessment of the funnel plot of standard error compared with the effect size estimate (Figure 3) from each study, we inferred

Table 5. Meta-regression of records included in a systematic review of precalving treatment for improving udder health in primiparous dairy heifers on the type of treatment assessed in the study

\begin{tabular}{lccc}
\hline Intervention type $^{1}$ & Risk ratio $^{2}(95 \% \mathrm{CI})$ & No. of records & Heterogeneity $^{3}$ \\
\hline Antimicrobial & $0.58(0.46-0.74)$ & 27 & \\
Teat sealant & $0.40^{4}(0.30-0.52)$ & 7 & $I^{2}=0.85$ \\
Teat dips/spray & $1.50^{4}(0.74-3.1)$ & 3 & $\mathrm{Q}=369.78$ \\
Vaccine & $0.55(0.35-0.86)$ & 12 & $P<0.0001$ \\
Combination & $0.34(0.25-0.45)$ & 4 & \\
Other & $0.50(0.11-1.1)$ & 4 & \\
\hline
\end{tabular}

${ }^{1}$ Antimicrobial includes antibiotics as well as antiseptic compounds such as chlorhexidine. Combinations in included studies consisted of teat sealants and antimicrobials; vaccines and antimicrobials; teat sealants, vaccines and antimicrobials. Other includes insecticides, and management practices such as prepartum milking (Appendix Table A1).

${ }^{2}$ Ratio of risk of infection in treated heifers to risk of infection in untreated controls.

${ }^{3}$ Residual heterogeneity from meta-regression model attributed to differences in studies. $I^{2}=$ statistic to quantify the amount of variation due to study heterogeneity; $Q=$ Cochrane $Q$ statistic for significance.

${ }^{4}$ Risk ratio different $(P<0.05)$ from studies assessing antimicrobial effectiveness. 
that some asymmetry due to missing studies showing an increased risk following treatment with small sample sizes (bottom right quadrant). Egger's regression small study effects indicated a possibility of publication bias as an increasing standard error was associated with a larger effect size estimate $(P<0.0001$; Figure 4$)$.

\section{DISCUSSION}

Management of mastitis on dairy farms often starts after the heifer's first calving, too often resulting in less than optimal udder health for first lactation heifers (De Vliegher et al., 2012). Many housing and management practices associated with udder health of older cows are also associated with improved udder health in primiparous heifers (De Vliegher et al., 2012), but the level of implementation in nonlactating heifers is unknown. Prophylactic treatments of the udder before calving (e.g., antimicrobial dry cow therapy or using internal teat sealants) are widely adopted for use in the lactating herd (e.g., Olde Riekerink et al., 2010), but these treatments are less commonly used in primipa- rous heifers. This systematic review and meta-analysis of studies assessing effectiveness of precalving therapies for improving postcalving udder health in heifers demonstrated an overall benefit to udder health in heifers when using any kind of precalving prophylactic treatment. Treatments varied in both cost to purchase as well as costs and labor associated with application, so an understanding of the effectiveness of treatments is important to inform management decisions. Effectiveness of treatments varied considerably and was also dependent on the type of bacteria causing the IMI.

This is the first review to meta-analyze results from studies of multiple types of precalving therapies in primiparous heifers. Recent reviews have considered heifer mastitis as a whole (De Vliegher et al., 2012), antimicrobial treatment to control heifer mastitis (Nickerson, 2009), vaccination efficacy against staphylococcal infections in all lactating cattle (Middleton et al., 2009), and effectiveness of treatments other than conventional antimicrobials against CM in all lactating cows (Francoz et al., 2017). The distribution of pathogens in IMI of heifers differs from older cows (Piepers et al., 2009;

Table 6. Meta-regression of records included in a systematic review of precalving treatment for improving udder health in primiparous dairy heifers on the type of treatment assessed in the study, stratified by type of pathogen

\begin{tabular}{|c|c|c|c|}
\hline $\begin{array}{l}\text { Pathogen and } \\
\text { intervention type }\end{array}$ & Risk ratio $^{3}(95 \%$ CI $)$ & No. of records & Heterogeneity $^{4}$ \\
\hline \multicolumn{4}{|l|}{ Contagious } \\
\hline Antimicrobial & $0.41(0.34-0.77)$ & 15 & \multirow{5}{*}{$\begin{array}{l}I^{2}=0.29 \\
\mathrm{Q}=39.36 \\
P=0.025\end{array}$} \\
\hline Teat sealant & $0.40(0.22-0.72)$ & 4 & \\
\hline Teat dips/spray & $1.48^{5}(0.52-4.27)$ & 1 & \\
\hline Vaccine & $0.56(0.34-0.92)$ & 8 & \\
\hline Combination & $0.93^{5}(0.33-1.26)$ & 1 & \\
\hline \multicolumn{4}{|l|}{ Environmental } \\
\hline Antimicrobial & $0.58(0.46-0.74)$ & 18 & \multirow{5}{*}{$\begin{array}{l}I^{2}=0.57 \\
\mathrm{Q}=71.77 \\
P<0.0001\end{array}$} \\
\hline Teat sealant & $0.27^{6}(0.15-0.49)$ & 5 & \\
\hline Teat dips/spray & $0.56(0.17-1.8)$ & 3 & \\
\hline Vaccine & $0.78(0.20-2.98)$ & 4 & \\
\hline Combination & $0.25^{6}(0.13-0.50)$ & 2 & \\
\hline \multicolumn{4}{|l|}{ CNS } \\
\hline Antimicrobial & $0.51(0.35-0.76)$ & 15 & \multirow{6}{*}{$\begin{array}{l}I^{2}=0.89 \\
\mathrm{Q}=212.71 \\
P<0.0001\end{array}$} \\
\hline Teat sealant & $0.46(0.29-0.73)$ & 4 & \\
\hline Teat dips/spray & $1.48(0.31-7.03)$ & 2 & \\
\hline Vaccine & $0.89(0.38-2.07)$ & 4 & \\
\hline Combination & $0.34^{6}(0.21-0.56)$ & 2 & \\
\hline Other & $0.80^{5}(0.19-3.34)$ & 1 & \\
\hline \multicolumn{4}{|c|}{$\begin{array}{l}{ }^{1} \text { Contagious pathogens include Staphylococcus aureus and Streptococcus agalactiae. Environmental pathogens } \\
\text { include Escherichia coli and non-agalactiae streptococci. }\end{array}$} \\
\hline \multirow{2}{*}{\multicolumn{4}{|c|}{$\begin{array}{l}{ }^{2} \text { Antimicrobial includes antibiotics as well as antiseptic compounds such as chlorhexidine. Combinations in } \\
\text { included studies consisted of teat sealants and antimicrobials; vaccines and antimicrobials; and teat sealants, } \\
\text { vaccines, and antimicrobials. Other includes insecticides and management practices such as prepartum milking } \\
\text { (Appendix Table A1). }\end{array}$}} \\
\hline & & & \\
\hline \multicolumn{4}{|c|}{$\begin{array}{l}{ }^{4} \text { Residual heterogeneity from meta-regression model attributed to differences in studies. } I^{2}=\text { statistic to quan- } \\
\text { tify the amount of variation due to study heterogeneity; Q }=\text { Cochrane Q statistic for significance. }\end{array}$} \\
\hline \multicolumn{4}{|c|}{$\begin{array}{l}{ }^{5} \text { Intervention type within pathogen type stratum did not have enough records for meta-analysis. Risk ratio } \\
\text { presented was calculated from the single record within that stratum. }\end{array}$} \\
\hline
\end{tabular}


Supré et al., 2011; Naqvi et al., 2018), as well as their immune response to infection (de Haas et al., 2002, 2004), so results from studies on older lactating cattle may not be generalizable to heifers. A synthesis of studies aimed at heifers in particular is therefore necessary when trying to implement more targeted management strategies. Findings from this review were in line with most individual studies and reviews on lactating cows that demonstrated a net positive benefit of any type of treatment for improving udder health. Previous reviews have demonstrated differential effectiveness of antimicrobials (Barkema et al., 2006; Nickerson, 2009) and teat sealants (Crispie et al., 2004), based on the pathogen (when used in lactating cows), whereas vaccine development tends to focus on a specific type of pathogen such as S. aureus (Middleton et al., 2009) or E. coli (Enviracor and StartVac). Compared with the present review focusing on heifers specifically, variation in treatment effectiveness by pathogen type was similar to previous reports from studies focusing on older cows.

As mentioned above, management of nonlactating heifers is less than ideal, with practices such as comingling with older cattle and moving cows close to calving and increasing stress being common on most dairy farms (Parker et al., 2007a; McDougall et al., 2009). This could be an important reason why treatments were effective in improving udder health. It is therefore likely that effectiveness of treatments, particularly antimicrobial treatment, will be less on farms that devote more attention to nonlactating heifers.

Although the effectiveness of antimicrobials was consistent across gram-positive pathogens, their use needs to be balanced with concerns about the rising prevalence of antimicrobial resistance (Barkema et al., 2015; Tang et al., 2017). To prevent overuse, the NMC's 10-point plan for heifer mastitis management recommends prepartum antibiotic treatment only under very specific conditions. Other treatments can be just as effective, if not more so, than antimicrobials in heifers, and current research is beginning to focus on their effectiveness in older cows (Francoz et al., 2017; Ruiz et al., 2017). Antimicrobial treatment of nonlactating heifers improved udder health more than other treatments when contagious (gram-positive) bacteria caused udder health problems after calving. In contrast, teat sealants and combination therapies were more effective than antimicrobial treatment when environmental pathogens were involved, suggesting that antimicrobials

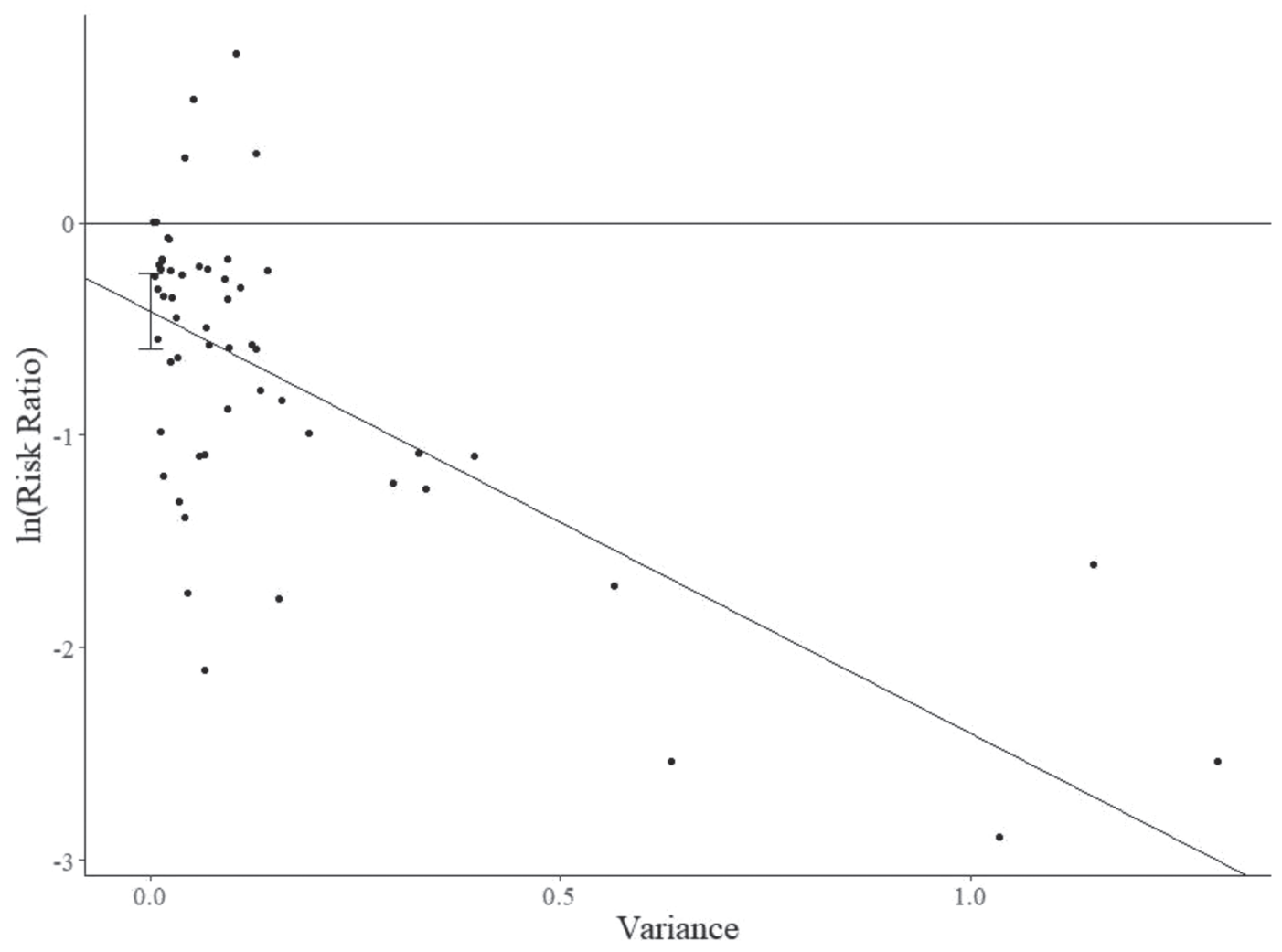

Figure 3. Egger's regression for small-study effects in a meta-analysis of studies assessing effectiveness of precalving therapies at improving udder health in dairy heifers plotted as the natural log of the risk ratio from a given study against the estimate of variance from the same study. Vertical bars indicate $95 \%$ confidence intervals at the intercept (variance $=0$; largest possible studies). 
are not always the best option. It is therefore important when udder health problems after calving are an issue on a farm and antimicrobial treatment is considered, to culture quarter milk of heifers after calving.

In addition to selecting the best treatment for each farm, personnel must also be properly trained in its application. For example, improper application of intramammary treatments, either causing trauma by inserting the cannula too far or using poor hygiene, can actually increase a quarter's risk of infection (du Preez, 2000). It is difficult to quantify the effect of iatrogenic infections in studies included in this review. Although some studies mentioned disinfection/preparatory procedures, no studies detailed training for personnel in treatment application. Safety of treatment application and ease of application may also vary by treatment type and should be considered when selecting a treatment. For example, feed supplements are much easier and safer to administer compared with prepartum intramammary infusions of antimicrobials. A comparison of systemic antibiotic treatment with those applied intramammarily could further inform decisions if they differ in effectiveness or ease of application. This comparison was not possible for the present review because intramammary infusions of antibiotics $(\mathrm{n}=31)$ greatly outnumbered systemically applied antimicrobials $(\mathrm{n}=$ 6 ), resulting in a lack of power due to the unbalanced groups. Similarly, a comparison of antimicrobial treatments based on classes may have resulted in differences in effectiveness; however, because the vast majority of antibiotic products used in the included studies were macrolides or macrolide combinations, lack of power

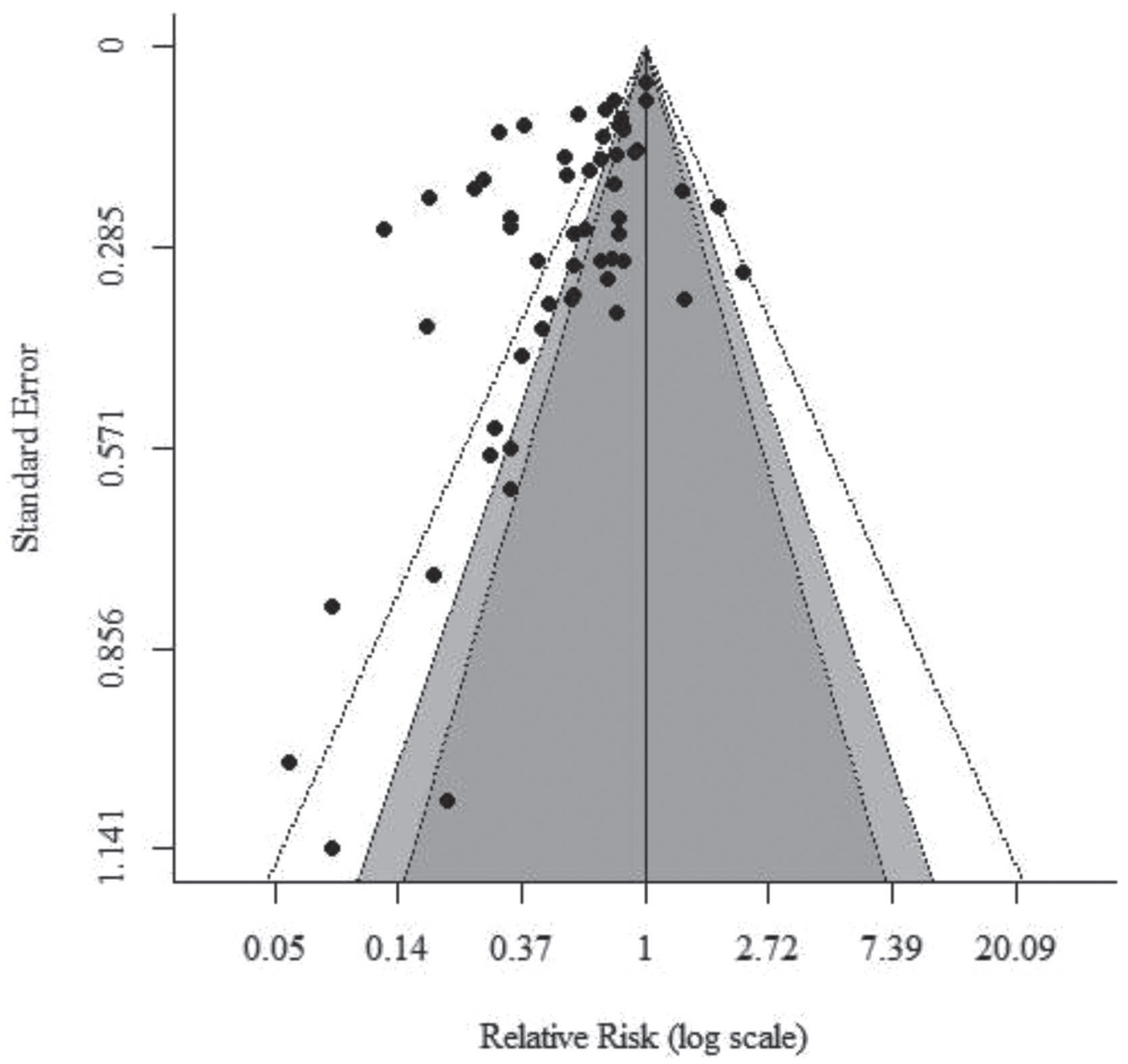

Figure 4. Funnel plot to assess asymmetry and publication bias in meta-analysis of studies assessing effectiveness of precalving therapies at improving udder health in dairy heifers. Relative risk $=1$ indicates equal risk of udder disease in treated and untreated animals (no effect of treatment). Darkest triangle indicates area of $90 \%$ confidence, light gray triangle indicates area of $95 \%$ confidence, and white triangle indicates area of $99 \%$ confidence. 
was again an issue. Nickerson (2009) provided a more comprehensive and in-depth review specific to antimicrobial treatments for heifers.

In comparing all types of treatments for heifers, this review faced the challenge of significant between-study variability, not only in treatments used, but also in other aspects of study design and setting. Although we tried to explore heterogeneity through subgroup analyses, many other study characteristics still varied considerably to allow for valid subgroup analyses (e.g., timing of treatment application, study location, timing of data collection, and geographic location). As a result, significant residual heterogeneity was present even after stratification. Although the significant between-study variability may cast some doubt on the precision of the pooled results, the overall message remains unchanged, as the direction of the effect remained consistent among studies, even if the effect size did not. Specifically, precalving treatment of heifers improved udder health after calving, and the degree of improvement varied by treatment type and pathogen. Variation in characteristics such as breed, geographic location, and sampling season or timing of treatment application and specific treatment are inherently linked, making it difficult to be consistent across studies from various countries and studying a variety of treatments.

An assessment of the risk of bias focuses on characteristics of study design and reporting in a way that is less dependent on factors outside of the researchers' control. The assessment using the SYRCLE tool (Hooijmans et al., 2014) highlighted some areas with significant risk of bias. Although randomization of housing and outcome assessment order are less likely to contribute to detection or performance bias in livestock studies (SYRCLE was designed for laboratory trials using animals), blinding of both treatment allocator or outcome assessor was not mentioned in most of the studies, nor was allocation concealment. For some outcomes (e.g., SCM or IMI), blinding may be inherent, because milk samples are collected by farm personnel and the outcome (SCC or bacterial culture) is assessed by laboratory technicians. Despite the possible inherent blinding of outcome assessors, lack of blinding of the treatment allocator could still contribute to detection bias, and both types of blinding should be reported, with justification provided if blinding was not done. Similarly, randomization and allocation sequence generation were only described in 6 studies, and presented a possible source of selection bias. Clear outcome definitions, especially for IMI, were also inconsistently reported; therefore, different definitions could contribute to residual heterogeneity. Although just defining IMI did not change effect size from studies that did not, looking at specific definitions would likely provide different results because each would have its own operating characteristics (Dohoo et al., 2011a,b). This likely is not a reflection of study quality, but more on inconsistency in reporting standards for studies on livestock. The Reporting Guidelines for Randomized Controlled Trials for Livestock (REFLECT; O'Connor et al., 2010) were developed to address this issue, but are still not widely implemented. Although this review reports on a substantial number of studies, an updated review in the future once the REFLECT statement is more widely implemented would likely detect more consistency among studies, leading to more precise pooled estimates of protective effect size.

As the first review to focus on the effectiveness of all existing precalving therapies at improving udder health in primiparous dairy heifers, the present study effectively synthesized results from a large number of studies. Heterogeneity was explored through subgroup analyses and meta-regression, focusing primarily on the main goals of the study: understanding variation in therapy success by treatment type and pathogen. Despite this exploration of heterogeneity, even stratification by both treatment type and pathogen still yielded significant residuals and unexplained study variability. As discussed, this was likely a reflection of differences in study settings, design characteristics, and reporting. Although this degree of study variability affected precision of pooled estimates, based on the direction of the effect, there was a positive effect on udder health when precalving treatments were applied. Publication bias in a review is another aspect that could affect the reliability of findings, and Egger's regression indicated that there were significant small-study effects in the review. Based on examination of the funnel plot, no studies had a negative effect of precalving treatment and used a small sample size. Although this may be a reflection of publication bias, in this case it is more clearly reflective of the true heterogeneity in the included studies, attributed primarily to treatment intensity and differences in underlying risk (Egger et al., 2008). Treatments varied considerably in timing of application and dosage, both of which would increase variability. Differences in geographical location, affecting housing, nutrition and other management factors, and animal breed could have contributed to differences in regional risks for mastitis, or differences in susceptibilities of heifers to disease. Asymmetry in the funnel plot may also be an artifact (Egger et al., 2008), as the majority of interventions under study were very unlikely to increase the risk of udder diseases over untreated heifers, making it very unlikely that small studies would show harm to udder health by precalving treatments. Although statistical evidence suggested publication bias, this was more 
likely a reflection of study variability as quantified by the residual heterogeneity rather than a bias in study selection.

\section{CONCLUSIONS}

In this first review of precalving treatments for improving udder health in primiparous dairy heifers, we assessed the findings of 60 studies, 48 of which were meta-analyzed for pooled estimates. Overall, any type of precalving therapy improved udder health by reducing occurrence of IMI, CM, and SCM compared with untreated controls. Variation in success by therapy type demonstrated that studies assessing antimicrobials, teat sealants, vaccines, and combination therapies demonstrated a significant reduction in the risk of udder disease, whereas those using teat dips/sprays or other types of therapy did not reduce risk compared with untreated heifers. There was also significant variation by pathogens that the studies examined: antimicrobials, teat sealants, vaccines, and combination therapies were effective at reducing risk of udder disease caused by contagious pathogens; antimicrobials, teat sealants, and vaccines were effective at reducing risk of udder disease caused by environmental pathogens; and finally, antimicrobials, teat sealants, vaccines, and combinations were effective at reducing udder disease caused by CNS. Once rigid reporting guidelines are more widely implemented by journals and authors, an updated literature review on udder health of dairy heifers should yield more precise pooled estimates, with decreased between-study variability.

\section{ACKNOWLEDGMENTS}

This study was supported by the Industrial Research Chair in Infectious Diseases of Dairy Cattle, funded by Canada's Natural Sciences and Engineering Research Council (NSERC) Industrial Research Chair Program (Ottawa, ON, Canada), with industry contributions from Alberta Milk (Edmonton, AB, Canada), the Dairy Farmers of Canada (Ottawa, ON, Canada), Westgen Endowment Fund (Milner, BC, Canada), the BC Dairy Association (Burnaby, BC, Canada), Canadian Dairy Network (Guelph, ON, Canada), CanWest DHI (Guelph, ON, Canada), and Dairy Farmers of Manitoba (Winnipeg, MN, Canada). The first and second authors were supported by a NSERC CREATE in Milk Quality Graduate student scholarship from the Canadian Bovine Mastitis and Milk Quality Research Network (Saint-Hyacinthe, QC). The first author was also supported by a Queen Elizabeth II scholarship from the province of Alberta. We also thank Todd Wilson and Karen Tang (teaching assistants for MDCH 741: Sys- tematic Reviews and Meta-Analysis at the University of Calgary) for their help in planning the review and refining research questions, Lorraine Toews (librarian at the Health Sciences Library at the University of Calgary) for her assistance in developing the database and gray literature search strategies, and John Kastelic (University of Calgary) for editing the manuscript.

\section{REFERENCES}

Acuña, C. N., G. F. Casasnovas, S. Terminiello, A. Moreno, C. G. Santarcangelo, and L. O. Simon. 2015. Use of dry cow therapy with internal teat sealant for the prevention of clinical mastitis occurring after calving in heifers with Staphylococcus aureus. Pages 171-172 in Proc. 54th NMC Annu. Mtg. NMC Proceedings Library, New Prague, MN.

Acuña, C. N., and R. E. Chertcoff. 2003. Mastitis control program on dairies with high incidence in first calving heifers: Part 2. In Proc. 42nd NMC Annu. Mtg.

Acuña Pasqualini, C. N., G. F. Casasnovas, and C. F. Macazaga. 2006. Effectiveness in the reduction of new intramammary infections in the dry period by the use of an external teat sealant in heifers at prepartum. Pages 258-259 in Proc. 45th NMC Annu. Mtg. NMC Proceedings Library, New Prague, MN.

Alaniz, G. R., T. R. Meinert, W. J. Loveland, G. Gallo, and S. A. Salmon. 2013. Evaluation of Escherichia coli bacterin, J-5 strain, as an aid in the control of clinical signs associated with E. coli mastitis in dairy cows. Pages 199-200 in Proc. 52nd NMC Annu. Mtg. NMC Proceedings Library, New Prague, MN.

Andersen, S., I. R. Dohoo, R. Olde Riekerink, and H. Stryhn. 2010. Diagnosing intramammary infections: Evaluating expert opinions on the definition of intramammary infection using conjoint analysis. J. Dairy Sci. 93:2966-2975. https://doi.org/10.3168/jds.2009 $-2726$.

Ataee, O., P. Hovareshti, M. Bolourchi, A. Barin, A. Gerami, and A. Niasari-Naslaji. 2009. Effect of systemic antibacterial administration during prepartum period on coagulase negative staphylococcal intramammary infection in Holstein heifers. Majallah-i Tahqiqat-i Dampizishki-i Iran 10:255-259.

Barkema, H. W., Y. H. Schukken, and R. N. Zadoks. 2006. Invited review: The role of cow, pathogen, and treatment regimen in the therapeutic success of bovine Staphylococcus aureus mastitis. J. Dairy Sci. 89:1877-1895. https://doi.org/10.3168/jds.S0022 -0302(06) 72256-1.

Barkema, H. W., M. A. G. von Keyserlingk, J. P. Kastelic, T. J. G. M. Lam, C. Luby, J.-P. Roy, S. J. LeBlanc, G. P. Keefe, and D. F. Kelton. 2015. Invited review: Changes in the dairy industry affecting dairy cattle health and welfare. J. Dairy Sci. 98:7426-7445. https://doi.org/10.3168/jds.2015-9377.

Barto, P. B., and L. J. Bush. 1978. Effect of prepartum antibiotic infusion on mastitis infection in dairy cows at first calving. Animal Science Research Report, Agricultural Experiment Station, Oklahoma State University (MP-103):164-168.

Bassel, L., D. Kelton, A. Godkin, K. Leslie, and K. Lissemore. 2003 Risk factors for intramammary infection at first calving in heifers from Ontario sentinel herds. Pages 282-283 in Proc. 42nd NMC Annu. Mtg. NMC Proceedings Library, New Prague, MN.

Bastan, A., M. Cengiz, S. Cengiz, B. Polat, A. Colak, M. Akan, I. Darbaz, and D. B. Acar. 2010. Effects of precalving antibiotic treatment on mastitis and individual somatic cell count in heifers. J. Anim. Vet. Adv. 9:1245-1249.

Borm, A. A., L. K. Fox, K. E. Leslie, J. S. Hogan, S. M. Andrew, K. M. Moyes, S. P. Oliver, Y. H. Schukken, D. D. Hancock, C. T. Gaskins, W. E. Owens, and C. Norman. 2006. Effects of prepartum intramammary antibiotic therapy on udder health, milk production, and reproductive performance in dairy heifers. J. Dairy Sci. 89:2090-2098. 
Bowers, S., S. Gandy, K. Graves, S. Eicher, and S. Willard. 2006 Effects of prepartum milking on postpartum reproduction, udder health and production performance in first-calf dairy heifers. J. Dairy Res. 73:257-263.

Bray, D. R., F. Elvinger, R. L. de la Sota, R. P. Natzke, P. A. Reed, and J. K. Shearer. 1989. Prevalence of infection in mammary quarters of nulliparous heifers and efficacy of intra-mammary infusion of antibiotics three weeks before parturition. J. Dairy Sci. 72(Suppl. 1):20.

Bryan, M., and K. Taylor. 2009. Periparturient use of parenteral micronised procaine penicillin to reduce the risk of clinical mastitis in heifers after calving. Vet. Microbiol. 134:143-149.

Bryan, M. A., and G. M. Friton. 2005. Stochastic economic modeling of the use of penethamate hydriodide (Mamyzin ${ }^{\circledR}$ ) in heifers around calving to control peri-parturient mastitis. Pages 232-234 in Mastitis in Dairy Production: Current Knowledge and Future Solutions. Wageningen Academic Publishers, Wageningen, the Netherlands.

Bush, L. J., P. B. Barto, and G. D. Adams. 1977. Effect of teat dipping on mastitis infection in dairy heifers at 1st calving. J. Dairy Sci. 60:167.

Compton, C., and S. McDougall. 2008. Effect of early milking of calved heifers and selenium supplementation on incidence of clinical mastitis in dairy heifers. Page 48 in Proc. 25th Jubilee World Buiatrics Congr. International Veterinary Information Service.

Compton, C. W. R., F. R. Emslie, and S. McDougall. 2014. Randomised controlled trials demonstrate efficacy of a novel internal teat sealant to prevent new intramammary infections in dairy cows and heifers. N. Z. Vet. J. 62:258-266.

Contreras, G. A., J. David Munoz, and P. M. Sears. 2013. Reducing the incidence of intramammary infection in heifers by using prepartum systemic tylosin therapy: Initial results of a single herd pilot study. Rev. Colomb. Cienc. Pecu. 26:119-126.

Crispie, F., J. Flynn, R. P. Ross, C. Hill, and W. J. Meaney. 2004 Dry cow therapy with a non-antibiotic intramammary teat seal-A review. Ir. Vet. J. 57:412-418. https://doi.org/10.1186/2046-0481 $-57-7-412$.

de Haas, Y., H. W. Barkema, and R. F. Veerkamp. 2002. The effect of pathogen-specific clinical mastitis on the lactation curve for somatic cell count. J. Dairy Sci. 85:1314-1323. https://doi.org/10 .3168/jds.S0022-0302(02)74196-9.

de Haas, Y., R. F. Veerkamp, H. W. Barkema, Y. T. Gröhn, and Y. H. Schukken. 2004. Associations between pathogen-specific cases of clinical mastitis and somatic cell count patterns. J. Dairy Sci. 87:95-105. https://doi.org/10.3168/jds.S0022-0302(04)73146-X.

De Vliegher, S., L. K. Fox, S. Piepers, S. McDougall, and H. W. Barkema. 2012. Invited review: Mastitis in dairy heifers: Nature of the disease, potential impact, prevention, and control. J. Dairy Sci. 95:1025-1040. https://doi.org/10.3168/jds.2010-4074.

Dohoo, I., S. Andersen, R. Dingwell, K. Hand, D. Kelton, K. Leslie, Y. Schukken, and S. Godden. 2011a. Diagnosing intramammary infections: Comparison of multiple versus single quarter milk samples for the identification of intramammary infections in lactating dairy cows. J. Dairy Sci. 94:5515-5522. https://doi.org/10.3168/jds.2011 -4486 .

Dohoo, I. R., J. Smith, S. Andersen, D. F. Kelton, and S. Godden 2011b. Diagnosing intramammary infections: Evaluation of definitions based on a single milk sample. J. Dairy Sci. 94:250-261. https://doi.org/10.3168/jds.2010-3559.

du Preez, J. H. 2000. Bovine mastitis therapy and why it fails. J. S. Afr. Vet. Assoc. 71:201-208. https://doi.org/10.4102/jsava.v71i3 .714 .

Duplessis, M., C. L. Girard, D. E. Santschi, J. P. Laforest, J. Durocher, and D. Pellerin. 2014. Effects of folic acid and vitamin B12 supplementation on culling rate, diseases, and reproduction in commercial dairy herds. J. Dairy Sci. 97:2346-2354. https://doi .org/10.3168/jds.2013-7369.

Edinger, D., B. A. Tenhagen, P. Kalbe, G. Klunder, B. Baumgartner, and W. Heuwieser. 2000. Effect of teat dipping with a germicide barrier teat dip in late gestation on intramammary infection and clinical mastitis during the first 5 days post-partum in primiparous cows. J. Vet. Med. A 47:463-468.
Egger, M., G. D. Smith, and D. G. Altman, ed. 2008. Systematic Reviews in Health Care: Meta-Analysis in Context. 2nd ed. BMJ Publishing Group, London, UK.

Francoz, D., V. Wellemans, J. P. Dupré, J.-P. Roy, F. Labelle, P. Lacasse, and S. Dufour. 2017. Invited review: A systematic review and qualitative analysis of treatments other than conventional antimicrobials for clinical mastitis in dairy cows. J. Dairy Sci. 100:77517770. https://doi.org/10.3168/jds.2016-12512.

Galphin, S. P., and E. Patrick. 1996. Evaluation of insecticide impregnated tail tags for preventing intramammary infection in dairy heifers. Page 78 in Proc. ADSA Dairy Foods Research Division. Am. Dairy Sci. Assoc., Champaign, IL.

Gentilini, M. B., L. R. Molina, and A. U. Carvalho. 2012. Use of an Escherichia coli J5 vaccine on immunization of dairy heifers against mastitis caused by E. coli. Arq. Bras. Med. Vet. Zootec. 64:67-74.

Gilbert, D. 2014. Use of internal teat sealants in pre calving heifers to control early lactational mastitis in UK. Cattle Pract. 22:275.

Giraudo, J. A., A. Calzolari, H. Rampone, A. Rampone, A. T. Giraudo, C. Bogni, A. Larriestra, and R. Nagel. 1997. Field trials of a vaccine against bovine mastitis. 1. Evaluation in heifers. J. Dairy Sci. 80:845-853.

Han, H. R., and H. M. Park. 1999. A field trial with a bovine staphylococcal mastitis vaccine in lactating cows and heifers. Pages 197198 in Proc. 38th NMC Annu. Mtg. NMC Proceedings Library, New Prague, MN.

Higgins, J. P. T., D. G. Altman, and J. A. C. Sterne, ed. 2011. Assessing risk of bias in included studies. In Cochrane Handbook for Systematic Reviews of Interventions. Version 5.1.0 [updated March 2011]. The Cochrane Collaboration, 2011.

Hooijmans, C. R., M. M. Rovers, R. B. De Vries, M. Leenaars, M Ritskes-Hoitinga, and M. W. Langendam. 2014. SYRCLE's risk of bias tool for animal studies. BMC Med. Res. Methodol. 14:43. https://doi.org/10.1186/1471-2288-14-43.

Hovareshti, P., M. Bolourchi, and A. H. Tabatabayi. 2007. Comparison of the effect of systemic and local antibacterial therapy to control staphylococcal intramammary infection in prepartum heifers. J. Vet. Res. (Pulawy) 62:7-9.

Jimenez, L., R. Timon, and J. Marco. 2008. Effect of Cefalonium on intramammary infections and on milk production of heifers before their first calving. Page 295 in Proc. 25th World Buiatrics Congress. International Veterinary Information Service.

Lopez-Benavides, M. G., R. T. Cursons, S. J. Lacy-Hulbert, and J. H. Williamson. 2009. Heifer teats sprayed in the dry period with an iodine teat sanitizer have reduced Streptococcus uberis teat-end contamination and less Streptococcus uberis intra-mammary infections at calving. Vet. Microbiol. 134:186-191.

Lopez-Benavides, M. G., J. H. Williamson, S. J. Lacy-Hulbert, and R. T. Cursons. 2006. Teat spraying prior to calving may reduce the risk of heifer mastitis caused by Streptococcus uberis. Proc. N.Z Soc. Anim. Prod. 66:168-171.

Matthews, K. R., R. J. Harmon, B. E. Langlois, W. L. Crist, and R. W. Hemken. 1988. Use of latex teat dip with germicide during the prepartum period. J. Dairy Sci. 71:1940-1946.

McCarthy, K. K., R. Kreft, and P. M. Sears. 2005. Effect of prepartum intramammary treatment in heifers on postpartum intramammary infections, somatic cell count and milk production. Pages 257-258 in Proc. 44th NMC Annu. Mtg. NMC Proceedings Library, New Prague, MN.

McDougall, S., K. Parker, C. Compton, and C. Heuer. 2005. Reducing subclinical and clinical mastitis in dairy heifers by precalving infusion of a teat sealant and/or parenteral antibiotic therapy. In Mastitis in Dairy Production: Current Knowledge and Future Solutions. H. Hogeveen, ed. Wageningen Academic Publishers, Wageningen, the Netherlands.

McDougall, S., K. I. Parker, C. Heuer, and C. W. R. Compton. 2009. A review of prevention and control of heifer mastitis via non-antibiotic strategies. Vet. Microbiol. 134:177-185. https://doi.org/10 $.1016 /$ j.vetmic.2008.09.026.

McDougall, S., K. I. Parker, A. M. Weir, and C. W. R. Compton. 2008. Effect of application of an external teat sealant and/or oral treatment with a monensin capsule precalving on the prevalence 
and incidence of subclinical and clinical mastitis in dairy heifers. N. Z. Vet. J. 56:120-129.

Middleton, J. R., C. D. Luby, and D. S. Adams. 2009. Efficacy of vaccination against staphylococcal mastitis: A review and new data. Vet. Microbiol. 134:192-198. https://doi.org/10.1016/j.vetmic .2008.09.053.

Middleton, J. R., C. D. Luby, B. J. Steevens, J. Lakritz, L. L. Timms, and G. R. Bader. 2005. Effect of prepartum intramammary treatment with pirlimycin hydrochloride on prevalence of early first-lactation mastitis in dairy heifers. J. Am. Vet. Med. Assoc. 227:1969-1974.

Naqvi, S. A., J. De Buck, S. Dufour, and H. W. Barkema. 2018. Udder health in Canadian dairy heifers during early lactation. J. Dairy Sci. In press.

National Mastitis Council (NMC). 2004. Recommended Mastitis Control Program. http://www.nmconline.org.

Neave, F. K., F. H. Dodd, R. G. Kingwill, and D. R. Westgarth. 1969. Control of mastitis in the dairy herd by hygiene and management. J. Dairy Sci. 52:696-707. https://doi.org/10.3168/jds.S0022 $-0302(69) 86632-4$.

Newton, H., and G. Chambers. 2014. Incidence of peri-calving clinical mastitis in maiden heifers treated with an internal teat sealant at varying precalving intervals. Pages 67-68 in Proc. 28th World Buiatrics Congr. International Veterinary Information Service.

Nickerson, S. C. 2009. Control of heifer mastitis: Antimicrobial treatment-An overview. Vet. Microbiol. 134:128-135. https://doi.org/ 10.1016/j.vetmic.2008.09.019.

Nickerson, S. C., and R. L. Boddie. 1990. Effects of novel intramammary devices on incidence of mastitis. Page 186 in Proc. 29th NMC Annu. Mtg. NMC Proceedings Library, New Prague, MN.

Nickerson, S. C., E. P. Hovingh, and P. W. Widel. 2008. Immunisation of dairy heifers with a Staphylococcus aureus bacterin reduces infection level and somatic cell counts at time of calving. Pages 119-123 in Mastitis Control: From Science to Practice. Wageningen Academic Publishers, Wageningen, the Netherlands.

Nickerson, S. C., W. E. Owens, and R. L. Boddie. 1994. Mastitis in dairy heifers: A historical review. Page 196 in Proc. ADSA Animal Health, Pharmacology and Toxicology Symposium. Am. Dairy Sci. Assoc., Champaign, IL

Nickerson, S. C., W. E. Owens, G. M. Tomita, and P. W. Widel. 1999. Vaccinating dairy heifers with a Staphylococcus aureus bacterin reduces mastitis at calving. Large Anim. Pract. 20:16-28.

Norman, C. B., W. E. Owens, R. L. Boddie, and C. H. Ray. 2003 Efficacy of prepartum, intramammary lactating cow antibiotics in dairy heifers. Pages 237-238 in Proc. 44th NMC Annu. Mtg. NMC Proceedings Library, New Prague, MN.

O'Connor, A. M., J. M. Sargeant, I. A. Gardner, J. S. Dickson, M. E. Torrence, C. E. Dewey, I. R. Dohoo, R. B. Evans, J. T. Gray, M. Greiner, G. Keefe, S. L. Lefebvre, P. S. Morley, A. Ramirez, W. Sischo, D. R. Smith, K. Snedeker, J. Sofos, M. P. Ward, and R. Wills. 2010. The REFLECT statement: Methods and processes of creating reporting guidelines for randomized controlled trials for livestock and food safety. J. Vet. Intern. Med. 24:57-64.

Olde Riekerink, R. G. H. W. Barkema, D. T. Scholl, D. E. Poole, and D. F. Kelton. 2010. Management practices associated with the bulk-milk prevalence of Staphylococcus aureus in Canadian dairy farms. Prev. Vet. Med. 97:20-28. https://doi.org/10.1016/ j.prevetmed.2010.07.002

Oliver, S. P., H. H. Dowlen, H. Moorehead, J. W. Hallberg, S. T. Chester, K. C. Lamar, S. J. Ivey, B. E. Gillespie, D. L. Johnson, and M. J. Lewis. 2004. Influence of prepartum pirlimycin hydrochloride or penicillin-novobiocin therapy on mastitis in heifers during early lactation. J. Dairy Sci. 87:1727-1731.

Oliver, S. P., S. I. Headrick, B. E. Gillespie, M. J. Lewis, D. L. Johnson, K. C. Lamar, H. Moorehead, H. H. Dowlen, and J. W. Hallberg. 2007. Intramammary infections in heifers during early lactation following intramammary infusion of pirlimycin hydrochloride or penicillin-novobiocin at the first milking after parturition. J. Dairy Res. 74:211-217.

Oliver, S. P., E. C. Jaenicke, R. K. Roberts, H. H. Dowlen, M. J. Lewis, and B. E. Gillespie. 2003. Prepartum antibiotic treatment of heifers: Milk production, milk quality and economic benefit. J. Dairy Sci. 86:1187-1193.

Oliver, S. P., S. H. King, M. J. Lewis, and H. H. Dowlen. 1992. Influence of prepartum antibiotic therapy on intramammary infections (IMI) in primigravid heifers during early lactation. J. Dairy Sci. 75:406-414.

Oliver, S. P., M. J. Lewis, B. E. Gillespie, and H. H. Dowlen. 1997a. Antibiotic residues and prevalence of mastitis pathogen isolation in heifers during early lactation following prepartum antibiotic therapy. J. Vet. Med. B 44:213-220.

Oliver, S. P., M. J. Lewis, B. E. Gillespie, and H. H. Dowlen. 1997b. Influence of prepartum antibiotic administration on intramammary infections in multiparous dairy cows during early lactation. Page 77 in Proc. ADSA Dairy Foods Research Division. Am. Dairy Sci. Assoc., Champaign, IL.

Owens, W. E., S. C. Nickerson, R. L. Boddie, G. M. Tomita, and C. H. Ray. 2001. Prevalence of mastitis in dairy heifers and effectiveness of antibiotic therapy. J. Dairy Sci. 84:814-817.

Parker, K. I., C. Compton, F. Anniss, and S. McDougall. 2007a. Management of dairy heifers and its relationships with the incidence of clinical mastitis. N. Z. Vet. J. 55:208-216.

Parker, K. I., C. Compton, F. M. Anniss, A. Weir, C. Heuer, and S McDougall. 2007b. Subclinical and clinical mastitis in heifers following the use of a teat sealant precalving. J. Dairy Sci. 90:207218

Parker, K. I., C. Heuer, S. McDougall, C. W. R. Compton, and F. M. Anniss. 2008. Quarter-level analysis of subclinical and clinical mastitis in primiparous heifers following the use of a teat sealant or an injectable antibiotic, or both, precalving. J. Dairy Sci. 91:169-181.

Passchyn, P., S. Piepers, and S. De Vliegher. 2013. Systemic prepartum treatment of end-term dairy heifers with penethamate hydriodide: Effect on udder health, milk yield, and culling until 120 days in milk. J. Dairy Sci. 96:6324-6335.

Passchyn, P., S. Piepers, and S. De Vliegher. 2014. Pathogen groupspecific risk factors for intramammary infection in treated and untreated dairy heifers participating in a prepartum antimicrobial treatment trial. J. Dairy Sci. 97:6260-6270. https://doi.org/ $10.3168 /$ jds.2014-8119.

Pellegrino, M., J. Giraudo, C. Raspanti, R. Nagel, L. Odierno, V. Primo, and C. Bogni. 2008. Experimental trial in heifers vaccinated with Staphylococcus aureus avirulent mutant against bovine mastitis. Vet. Microbiol. 127:186-190.

Pellegrino, M., J. Giraudo, C. Raspanti, L. Odierno, and C. Bogni. 2010. Efficacy of immunization against bovine mastitis using a Staphylococcus aureus avirulent mutant vaccine. Vaccine 28:45234528.

Piepers, S., S. DeVliegher, A. DeKruif, G. Opsomer, and H. W. Barkema. 2009. Impact of intramammary infections in dairy heifers on future udder health, milk production, and culling. Vet. Microbiol. 134:113-120. https://doi.org/10.1016/j.vetmic.2008.09.017.

Pol, M., M. Ebinger, and A. Castelletti. 2015. Efficacy of precalving treatment with parenteral danofloxacin in heifers. Pages 207-208 in Proc. 54th NMC Annu. Mtg. NMC Proceedings Library, New Prague, MN.

Pyörälä, S. 2008. Mastitis in post-partum dairy cows. Reprod. Domest. Anim. 43:252-259. https://doi.org/10.1111/j.1439-0531.2008 .01170.x.

Robertson, B. G., J. H. Williamson, B. Kuhn-Sherlock, S. J. LacyHulbert, and S. A. Turner. 2017. Use of internal teat sealant in heifers reduces mastitis and may affect milk production. Anim. Prod. Sci. 57:1494-1498.

Roger, N., and L. M. Jiménez. 2013. Case study: Udder health in heifers after vaccination against mastitis. Pages 197-198 in Proc. 52nd NMC Annu. Mtg. NMC Proceedings Library, New Prague, MN.

Roy, J. P., D. Du Tremblay, L. DesCôteaux, S. Messier, D. Scholl, and É. Bouchard. 2007. Effect of precalving intramammary treatment with pirlimycin in nulliparous Holstein heifers. Can. J. Vet. Res. 71:283-291.

Ruiz, R., L. O. Tedeschi, and A. Sepúlveda. 2017. Investigation of the effect of pegbovigrastim on some periparturient immune disorders 
and performance in Mexican dairy herds. J. Dairy Sci. 100:33053317. https://doi.org/10.3168/jds.2016-12003.

Sampimon, O. C., S. de Vliegher, H. W. Barkema, J. Sol, and T. J. G. M. Lam. 2009. Effect of prepartum dry cow antibiotic treatment in dairy heifers on udder health and milk production. J. Dairy Sci. 92:4395-4403.

Santos, J. E. P., R. L. A. Cerri, J. H. Kirk, S. O. Juchem, and A. Villasenor. 2004. Effect of prepartum milking of primigravid cows on mammary gland health and lactation performance. Livest. Prod. Sci. 86:105-116.

Seegers, H., C. Fourichon, and F. Beaudeau. 2003. Production effects related to mastitis and mastitis economics in dairy cattle herds. Vet. Res. 34:475-491. https://doi.org/10.1051/vetres:2003027.

Shamseer, L., D. Moher, M. Clarke, D. Ghersi, A. Liberati, M. Petticrew, P. Shekelle, L.A. Stewart, and PRISMA-P Group. 2015. Preferred reporting items for systematic review and meta-analysis protocols (PRISMA-P) 2015: elaboration and explanation. BMJ 350:g7647. https://doi.org/10.1136/BMJ.G7647.

Supré, K., F. Haesebrouck, R. N. Zadoks, M. Vaneechoutte, S. Piepers, and S. De Vliegher. 2011. Some coagulase-negative Staphylococcus species affect udder health more than others. J. Dairy Sci. 94:2329-2340. https://doi.org/10.3168/jds.2010-3741.

Tang, K. L., N. P. Caffrey, D. B. Nóbrega, S. C. Cork, P. E. Ronksley, H. W. Barkema, A. J. Polachek, H. Ganshorn, N. Sharma, J. D. Kellner, and W. A. Ghali. 2017. Restricting the use of antibiotics in food-producing animals and its associations with antibiotic resistance in food-producing animals and human beings: A systematic review and meta-analysis. Lancet Planet Health 1:316-327. https://doi.org/10.1016/S2542-5196(17)30141-9.
Tenhagen, B. A., D. Edinger, B. Baumgartner, P. Kalbe, G. Klunder, and W. Heuwieser. 2001. Efficacy of a herd-specific vaccine against Staphylococcus aureus to prevent post-partum mastitis in dairy heifers. J. Vet. Med. A 48:601-607.

Timms, L. L., A. Steffens, and L. Allen. 1997. Field trial evaluation of a persistent barrier teat dip for preventing mastitis during the dry period. Page 173 in Proc. ADSA Dairy Foods Research Division. Am. Dairy Sci. Assoc., Champaign, IL.

Toušová, R., L. Stádník, J. Ducháček, and M. Baráková. 2011. Influence of vaccination against mastitis on its incidence, somatic cells amount and content of solid components in milk of primiparous dairy cows. Vyzk. Chovu Skotu 53:84-90.

Trinidad, P., and S. C. Nickerson. 1989. Prevalence and treatment of intramammary infections in breeding age and in pregnant dairy heifers. Page 220 in Proc. 28th NMC Annu. Mtg. NMC Proceedings Library, New Prague, MN.

Trinidad, P., S. C. Nickerson, T. K. Alley, and R. W. Adkinson. 1990. Efficacy of intramammary treatment in unbred and primigravid dairy heifers. J. Am. Vet. Med. Assoc. 197:465-470.

Vargas, R. T., F. N. Souza, M. A. V. P. Brito, J. R. F. Brito, M. O. Leite, L. M. Fonseca, I. B. M. Sampaio, and M. M. O. P. Cerqueira. 2016. Partial budget analysis of prepartum antimicrobial therapy and Escherichia coli J5 vaccination of dairy heifers and their effect on milk production and milk quality parameters. Pesqui. Vet. Bras. 36:77-82.

Viechtbauer, W. 2010. Conducting meta-analyses in R with the metafor package. J. Stat. Softw. 36:1-48. https://doi.org/10.18637/jss .v036.i03.

\section{APPENDIX}

The following search terms were used in database searches. The MeSH search is integrated in the Web of Science, so the same terms were employed there.

The search terms used were separated into 3 separate components corresponding to the study population, intervention, and outcome type. Each of these was combined with the Boolean operator AND. Subject heading searches were conducted separately from the text search as the available subject headings were not comprehensive.

1) To identify studies with a study population looking at heifers and not just all cows grouped together, the search was split into 2 parts (to ensure that the age of animals in the study was appropriate, as well as restrict our search to dairy cows only), which were combined using the Boolean operator AND:

a. The terms "dairy" and "milk*" combined with the Boolean operator OR. The corresponding subject headings were "dairy herds," "dairy cows," "dairy cattle," and "milking" combined with the operator OR.

b. The terms "heifer*," "primiparous," "primigravid," "nulliparous" combined with the Boolean operator OR. The corresponding subject headings were "heifers" and "bred heifers" combined with the Boolean operator OR.
2) To identify studies with the relevant interventions, the search was again split into 2 parts (timing of intervention had to be precalving, as well as specify all types of intervention), which were again combined using the Boolean operator AND:

a. The terms "precalving," "prepartum," and "calving" combined with the Boolean operator OR. The corresponding subject heading search terms were "calving" and "prepartum period" combined using the operator OR.

b. The terms "therap*," "treat*," "antimicrob*," "antibiotic," and "seal*" combined using the operator OR. The corresponding subject headings were "drug therapy," "therapy," "treatment," and "combination therapy" combined using the Boolean operator OR.

3) To identify all possibly relevant outcomes the search terms used were "mastit*," "infect*," "clinical mastit*," "bacteri*," "inflam*," "pathogen," and "microorganism" combined using the Boolean operator OR. The corresponding subject headings used were "mastitis," "summer mastitis," "subclinical mastitis," "mycotic mastitis," "bovine mastitis," and "inflammation" combined using the Boolean operator OR. 
Table A1. Details on product used, primary therapeutic ingredient(s), method of application, and categorization of intervention for each of the 62 studies $^{1}$

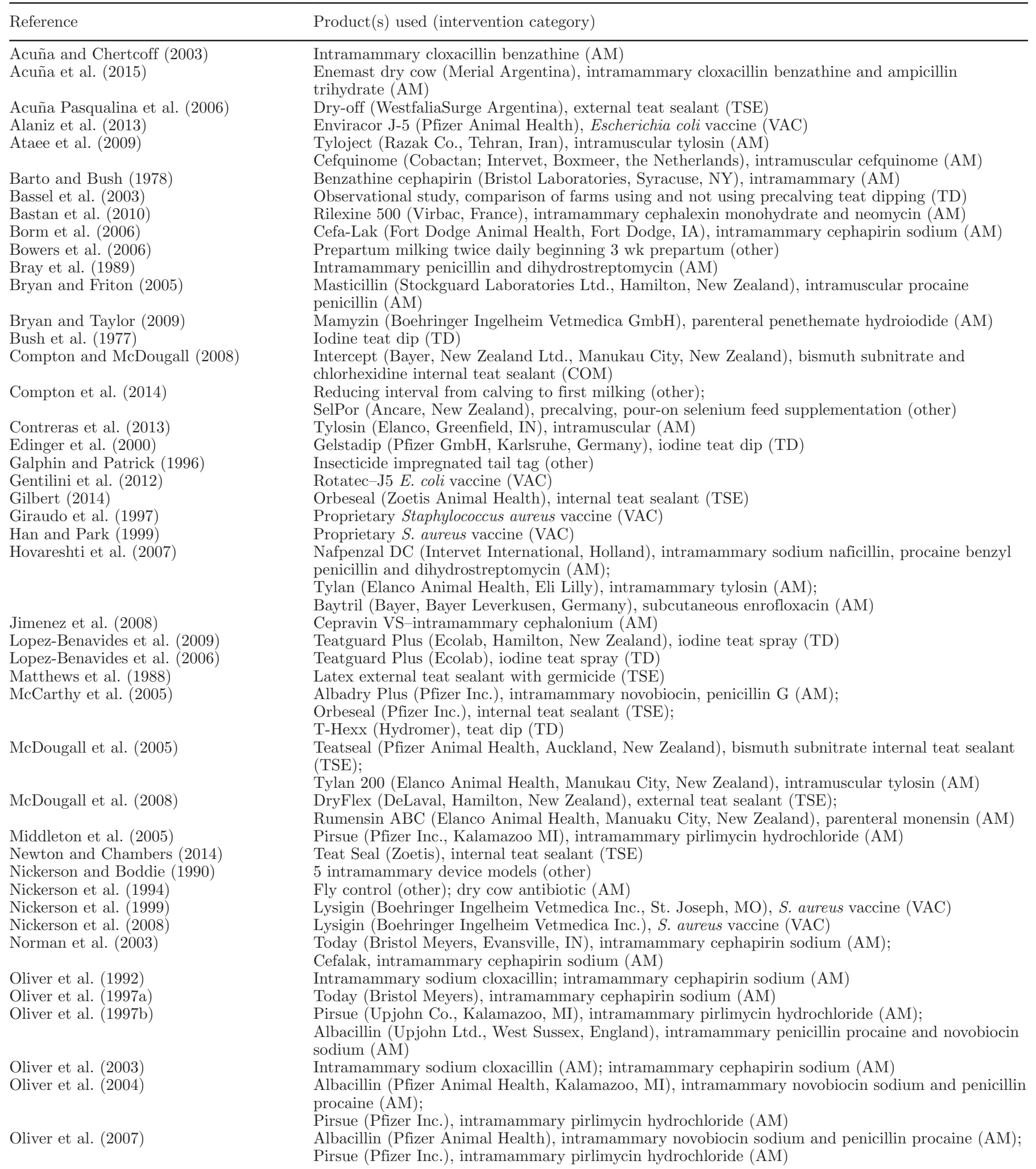


Table A1 (Continued). Details on product used, primary therapeutic ingredient(s), method of application, and categorization of intervention for each of the 62 studies $^{1}$

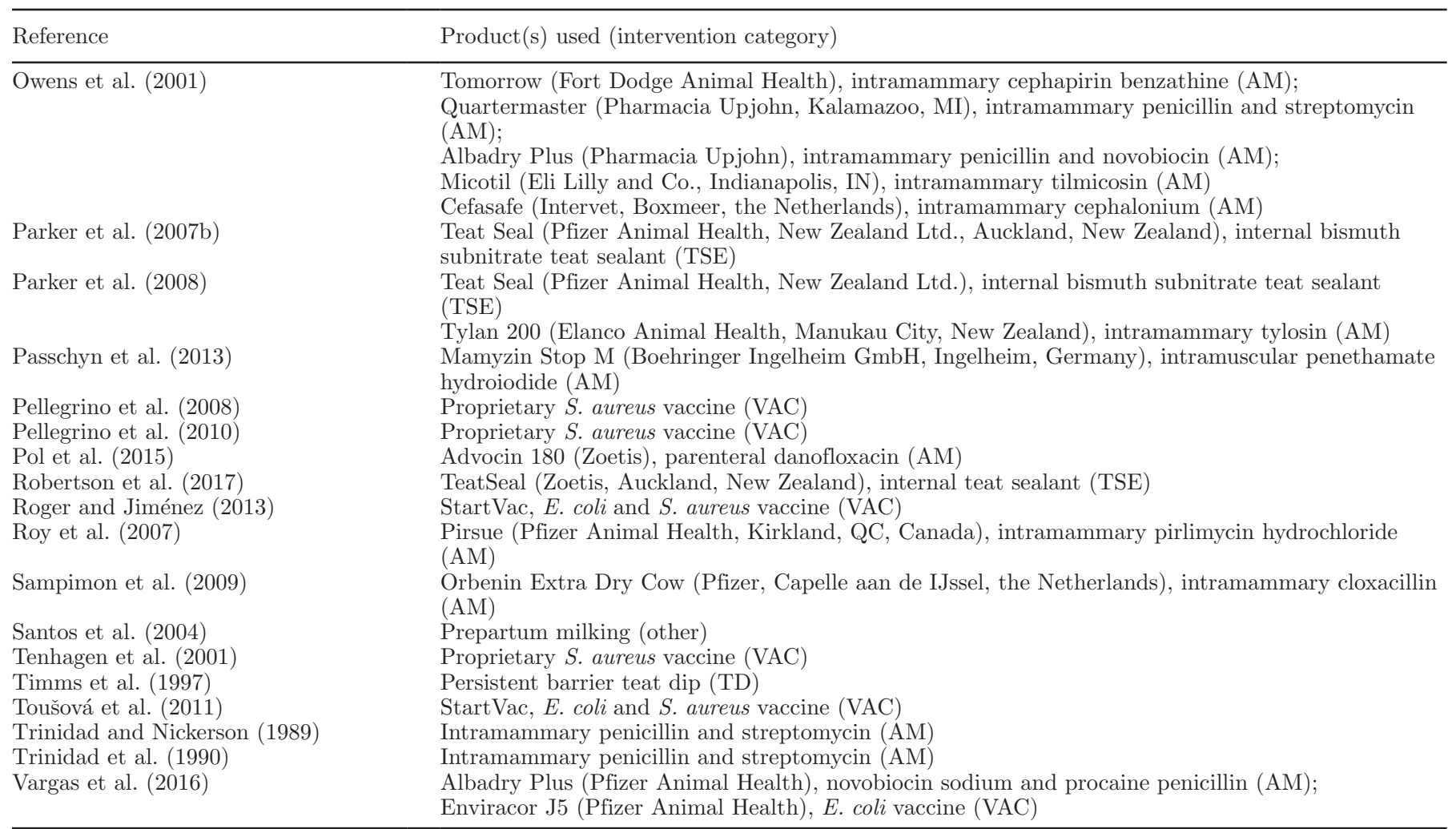

${ }^{1} \mathrm{AM}=$ antimicrobial; TSE $=$ teat sealant; $\mathrm{TD}=$ teat dips/sprays; VAC = vaccine; $\mathrm{COM}=$ combination of multiple types. 